\title{
Firm Dynamics and Aggregate Growth: The Case of Hungary*
}

\author{
Péter Bauer - Marianna Endrész
}

This paper reports some stylised facts on firm dynamics in Hungary for the period 2001-2015. We find that young firms tend to be small. They grow fast, but at the same time they are risky, have a high exit rate and their productivity is lower than that of older firms. Despite their small share in aggregate output, their contribution to aggregate growth is significant. Their dynamism comes from their young age rather than from their small size. Export performance is somewhat different, as older firms remain more active and make a significant contribution to aggregate growth. During the crisis, young firms still made a positive contribution to growth, but the deteriorating performance of older firms dominated the aggregate picture, because of their large share in production. The behaviour of firm groups by size and age varied during the crisis and the recovery. Interestingly, the recovery seems to be dominated by the lower-end of the distribution of firm population; destruction eased and fewer firms exited, but there was no recovery in gross creation. Firm entry kept falling even during the recovery period, which must have contributed to the sluggish, weak recovery.

Journal of Economic Literature (JEL) codes: D22, L25

Keywords: firm dynamics, firm life-cycle, crisis, economic growth, empirical analysis

\section{Introduction}

Analysis of the drivers and constraints of economic growth is at the heart of economic policy research. The literature is very rich, covering various aspects of growth such as institutions, competition, technological waves, innovation and international trade. In this study, we focus on firm dynamics and their relation to and impact on aggregate growth. What can firm-level analysis add to the understanding of aggregate growth? The behaviour of firms is heterogeneous, their dynamics vary by age and size, and entry and exit can become important drivers of the level and pace of aggregate growth. The analysis of firm dynamics and their evolution

\footnotetext{
* The papers in this issue contain the views of the authors which are not necessarily the same as the official views of the Magyar Nemzeti Bank.

Péter Bauer is a Senior Economic Analyst at Magyar Nemzeti Bank. E-mail: bauerp@mnb.hu Marianna Endrész is an Economic Research Expert at Magyar Nemzeti Bank. E-mail: valentinyinem@mnb.hu The English manuscript was received on 19 December 2017.
}

DOI: http://doi.org/10.25201/FER.17.2.6898 
over time may provide insights on where growth comes from, on differences during phases of the business cycle or the existence of constraints. It allows us to investigate questions such as whether small or young firms grow quickly? Is the cost of entry high or is it more so growth that is constrained? How do firm dynamics change during a financial crisis? Answers to these questions can help to identify the sources of and constraints on growth and elaborate growth-enhancing economic policies. This paper takes a first step in this direction by reporting basic observations on firm dynamics.

The empirical literature on firm dynamics documents the following observations: (1) young firms tend to be small and their size distribution is skewed; (2) small firms are more likely to exit, but conditional on survival they grow faster than large firms; (3) age and size are positively correlated; (4) the reallocation of inputs from less productive firms to more productive incumbents or new entrants is a key source of productivity growth (see Bartelsman et al. 2004, López-Garcia and Puente 2006, Békés et al. 2011, Andersson 2006). Findings on the link between size and growth were later challenged by Haltiwanger et al. (2013) and Criscuolo et al. (2014), who show that the importance of small firms in employment creation comes more from their young age, rather than from their small size. The theoretical models which are best at predicting these empirical regularities are Schumpeterian growth theories, relying on the notion of creative destruction (see Aghion et al. 2014). Schumpeter regarded innovation as the driver of growth. As new technology replaces old ones, growth materialises through creative destruction. Creative destruction involves the entry of new firms, reallocation of inputs and is mostly consistent with the empirical observations of firm dynamics.

Related previous literature on Hungarian data focuses on the decomposition of aggregate productivity growth. Békés et al. (2011) analyse manufacturing for the period 1992-2006. They find that growth in aggregate productivity is mainly due to productivity growth at continuing firms, although the reallocation of inputs and creative destruction also had some positive impact. Brown and Earle (2008) analyse manufacturing firm data for some transition countries, including Hungary, documenting how reallocation changed following the transition.

We use firm-level data to investigate some features of firm dynamics in the Hungarian economy for the period 2001-2015 and to document the impact of the recent financial crisis. The analysis focuses on aggregate growth. We evaluate the growth performance of firms and its link to age. Following the works of Haltiwanger et al. $(2013,2016)$, we also discuss whether firm size or age is important for growth. During the recent crisis the entry of firms fell to historically low levels in many countries, causing a persistent slowdown and weak recovery. Therefore, we investigate the role played by entry and exit in general and during the crisisrecovery period in particular. Our analysis also builds on the firm life cycle literature: 
in addition to entry, exit and output growth, other aspects of firm performance exports, productivity and bank borrowing - and their changes with the age of the firm are also analysed.

This paper is the first of its kind on Hungarian data. We cover almost the entire firm population. We deviate from the literature on firm dynamics, which focuses on employment creation as a measure of growth. Instead, we use real value added. Our dataset is novel in the sense that we fully control for all kinds of firm transformations, including mergers and acquisitions, or one-to-one transformations. Our paper does not cover the decomposition of productivity, which can be considered as a natural extension of our work on firm dynamics and is left for future research.

The next section introduces the datasets used and the methodology. The following sections each discuss one performance measure, covering its relation to age, behaviour during distinct time-periods and the age-size debate. We start with real value added, which is followed by productivity, exports and bank borrowing. Finally, we present our conclusions.

\section{Data and methodology}

We use three databases for our analyses: annual balance sheet and income data of double bookkeeping firms from the Hungarian tax authority (NAV), the registry of firms from the Hungarian Central Statistical Office (KSH), and bank lending data from the Central Credit Information System (KHR).

Balance sheet and income data are used to create the main firm-level variables. Thus, we conduct our analyses with annual frequency between 2001 and 2015. Value added is calculated from turnover and various cost items. Firms are classified into 2-digit sectors based on their 4-digit NACE numbers. We dropped the financial sector and the oil production sector due to data issues. Nominal variables are deflated by official, 2-digit sector level deflators to create real variables (the implicit value added deflator for value added and PPI for exports). We use employment and real value added to calculate labour productivity.

We also use total assets, turnover and employment from this database to classify firms into size classes: micro, small, medium and large. The definition is very similar to the official SME categories where the thresholds are the following: for employment: 10, 50, 250 persons; for sales: 2, 10, 50 million euros; for total assets: 2, 10, 43 million euros. We classify a firm into a higher category if any of the three variables exceeds the relevant threshold which is different from the official definition where employment or both sales and total assets must exceed 
the threshold. ${ }^{1}$ If employment is missing, we classify the firm based on the other two variables (there are no missing values for turnover or total assets).

We calculate two indicator variables for credit from KHR that show if a firm has a credit relationship with a financial institution. The first one is a flow variable defined as 1 if the firm takes out a new loan in the given period, otherwise it is zero. The second one is a stock variable defined as 1 if the firm has loan in the given period, otherwise it is zero. The data from KHR is available from 2005, and thus we analyse lending only for the period 2005-2015.

We use so-called mid-point growth rates for value added and exports proposed by Davis, Haltiwanger and Schuh (1996) and applied in several papers on firm dynamics (e.g. Haltiwanger et al. 2016). The growth rates are calculated as follows:

$$
X_{i t}^{g r}=\frac{X_{i t}-X_{i t-1}}{0.5 *\left(X_{i t}+X_{i t-1}\right)}
$$

This has several advantages compared to the usual percentage changes or log difference, however it can be approximated by the latter. Its range is bounded between -2 and 2; it is symmetric in the sense that if we exchange $X_{i t}$ with $X_{i t-1}$ then the growth rate will be the same in absolute value with the opposite sign (true for log difference as well). From that it follows that if there is an increase and then a decrease back to the same value, then the sum of the growth rates is zero. A huge advantage is that zero values of $X$ are not omitted: ${ }^{2}$ so, entry and exit have a growth rate of 2 and -2 , respectively (not true for log difference, and percentage change is only meaningful for exit, when it is -100 per cent). ${ }^{3}$ Another advantage is that it can be easily aggregated: if we calculate the weighted average of mid-point growth rates with the mid-point weights (i.e. the average value of $t$ and $t-1$ ) we arrive at the aggregated mid-point growth rate: $\left(X_{t}-X_{t-1}\right) /\left(0.5 *\left(X_{t}+X_{t-1}\right)\right)$, where $X_{t}=\sum_{i=1}^{n_{t}} X_{i t}$ and $n_{t}$ is the number of firms in $t$.

\footnotetext{
${ }^{1}$ We deviate from the official rule to correct for greenfield investments by multinationals when in the first couple of years the subsidiaries have only a handful of employees and no turnover, but total assets are large. ${ }^{2}$ Some firms have negative value added. As neither the mid-point nor the growth rate can be meaningfully estimated with negative values, negative Rva is always replaced with zero. As a result, the total real value added is raised by 3-4 per cent on average, but its dynamics hardly change. Another consequence of this assumption is that we are likely to slightly underestimate the fall/rise during the crisis/recovery, as changes between negative (and zero) values are ignored.

${ }^{3}$ For entry, we check whether there is an observation in the previous year. If not, we define the growth rate as 2. For exit, we create artificial observations in the next year, and the growth rate then will be defined as -2 .
} 
We usually interpret the mid-point growth rate figures in this paper as percentage changes, which is quite similar to the generally accepted interpretation of logarithmic differences. For example, if the mid-point growth rate is 0.05 , then we say that the growth rate is 5 per cent. The bias of this kind of interpretation is small when the growth rates are low, e.g. in the former case the actual growth rate compared to the previous period is 5.1 per cent. But the bias can be quite large or even infinite in case of larger growth rates (in absolute value). For example, if the mid-point growth rate is 1 , then the actual growth rate compared to the previous period is 200 per cent and not 100 per cent. If the mid-point growth rate is 2 , then the actual growth rate is infinite as this can only be possible in case of zero value in the previous period. So, in the case of growth rates of 2 or -2 , we will not interpret these as 200 or -200 per cent rates.

The registry of firms is used to calculate the age of firms based on their foundation year. The age is 1 in the foundation year by our definition (versus 0 in some other papers in the literature). For value added, we define entry in the year when the firm was founded (i.e. when its age is 1) or in the year when it first appears in the database. An exception is the year 2004, when all firms had to switch to doubleentry bookkeeping and thus older, previously single-entry bookkeepers appear in our database. Firm transformations are also handled as an exception, as described in more detail in the following paragraph on mergers and acquisitions. Exit is defined as the last observation of a firm in the database. For exports, we use a different entry and exit definition, as the beginning and end of export activity is not directly linked to the foundation and liquidation of firms. Thus, entry in this case is the beginning of export activity and exit is the end of export activity. For exports, in contrast to the case of value added, we allow multiple entries or exits by a firm.

The registry of firms also contains information on mergers and acquisitions and other types of firm transformations (hereinafter: M\&A). ${ }^{4}$ We use this information to consider M\&A in the calculation of age and the dynamics of value added and exports. Firms' age is always calculated based on the age of the oldest firm that was part of the M\&A. For example, if $A$ and $B$ firm merge in year $t$ and the new firm is $C$ in year $t+1$, then the age of $C$ will be the age of the older one of $A$ and $B$, plus one, because of the year that passed. Moreover, we consider neither $A$ nor $B$ as exiting firms or $C$ as an entering firm. We also correct the dynamics for M\&A activity: growth rates of variables are calculated as if we consolidate firms that engage in M\&A in the same year, weights (mid-point values) are set that the aggregate dynamics do not change. In the above example, if $A$ and $B$ firm merge in year $t$ and the new firm is $C$ in year $t+1$, the growth of the value added for $C$ will be calculated as growth of the aggregate firm $A+B$ to firm $C$. In the case of division of

${ }^{4}$ Other types of transformations include divestment of firms and simple one-to-one transformation. 
firms, e.g. $D$ to $E$ and $F$, growth rates for $E$ and $F$ will be calculated as growth of $D$ to the aggregate firm $E+F$, and will be the same for $E$ and $F$. In this case, the weights will be set that they reflect the relative share of $E$ and $F$ in $E+F$ and thus the aggregate growth rate does not change.

In the analysis, we almost always use weighted growth rates (or weighted levels in the case of productivity) or weighted regressions to draw conclusions about aggregate effects. Without weights, micro firms would dominate all the results. The weights are the mid-point values (average of $t$ and $t-1$ ) in the case of value added and exports, and actual employment in the case of productivity. In the case of entry and exit, the mid-point values are calculated as expected: a missing value is considered as zero, and so the weight will be half of the value of the first (last) observation. In this way, the weighted average of dynamics is the same as the dynamics of the aggregated values (value added or exports).

When the regression is run, year fixed effects and 2-digit NACE sector fixed effects are always controlled for. Other explanatory variables (age and size dummies) are added depending on the specification.

We study firm performance in the following dimensions: age, where we use the following categories: 1 to 14 -year-old firms, and 15-year old or older firms (15+); size: we use the usual categories: micro, small, medium, large firms; time: we define 3 periods: before crisis (pre-crisis: 2001-2007), crisis (2008-2012) and recovery (2013-2015).

\section{Firm size, dynamics and age - Real value added}

First, we document the stylised features of Hungarian firms' dynamics relating to size, age, growth and volatility. To analyse the changing dynamics of firms along their life cycle we use real value added (Rva). Similar papers often concentrate on employment. Because of data unavailability, studies using other, output-type measures are still scant (one exception is Haltiwanger et al. 2016). Another reason for analysing Rva instead of employment is that the impact of age and size on employment creation is extensively studied by Benk - Morvay - Telegdy (2018).

New entrants tend to be small. Figure 1 (upper panel) shows that there is a positive correlation between age and size. The correlation remains even if we run regression and control for time trends and sector fixed effects (regression results are not shown here). 


\section{Figure 1 \\ Size distribution by age (upper panel) and weighted Rva growth rate by age (lower panel)}

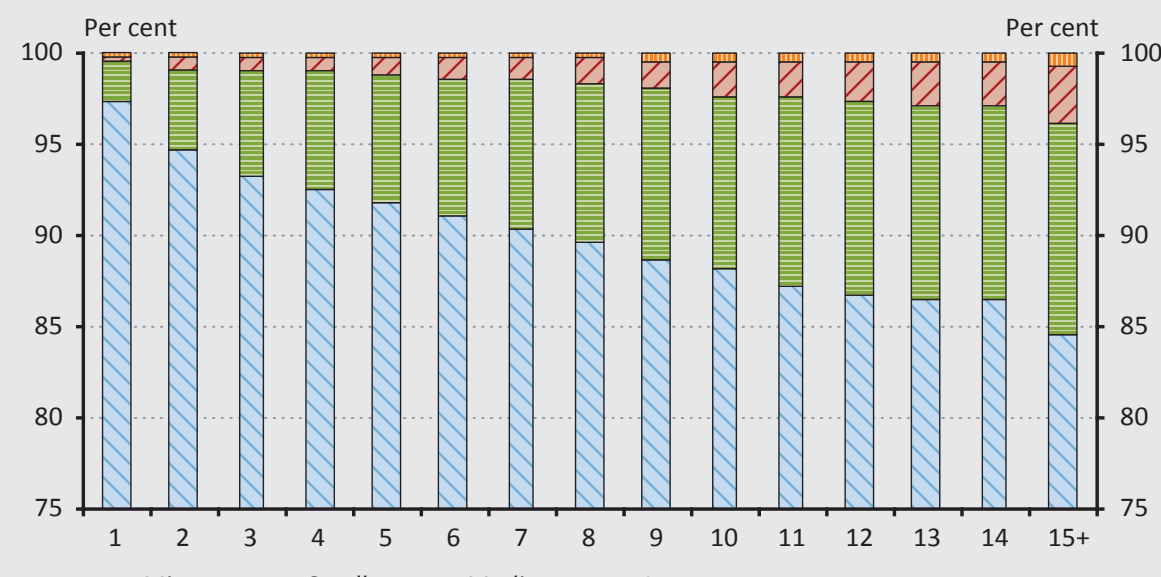

$\square$ Micro $\rightleftharpoons$ Small $\square$ Medium

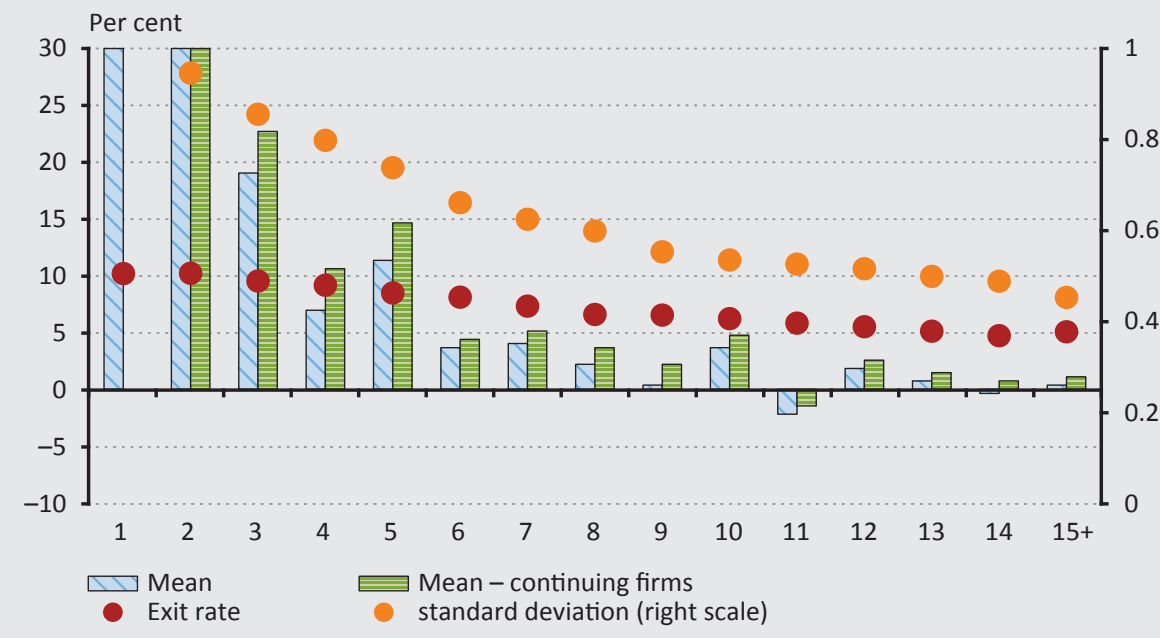

Note: The left axis of the lower panel is truncated at 30 per cent. 
New entrants are not just small, they are extremely dynamic, exhibiting a very high growth rate during the first years of their existence (see lower panel of Figure 1). For example, 3-year-old firms ${ }^{5}$ grow at a rate of around 20 per cent on average over 2001-2015. Following the 5th or 6th year (in life-cycle analysis that age is often found to be the time when firms become mature and start slowing down), the growth rates fall significantly, below 5 per cent, and above 10 years, firms hardly grow (max. 1-2 per cent). ${ }^{6}$

Although young firms tend to grow rapidly, their performance is dispersed - shown by the standard deviation of growth rate by age groups - and their exit rate is high (see lower panel of Figure 1). For example, firms up to the age of 3 years have at least a 10 per cent probability of exiting. Firms go through a selection process after entering, and only the viable firms survive. Exits have a non-negligible impact on the growth rate of each age group as well - this is captured by the difference between the two columns (Figure 1, lower panel), the one calculated for continuing and the other for the entire sample, including exiting firms. All of these measures - the exit rate, its impact on growth and the dispersion of the growth rate - decline with age.

To assess the aggregate significance of the observed dynamism of young firms, the aggregate growth rate of real value added is decomposed into four age groups (Figure 2, upper panel). We find that the contribution to aggregate growth declines with age. Most strikingly, despite the low weight of the youngest group (1-4 years), which produces only 7 per cent of total real value added, 70 per cent of growth is attributed to them. By contrast, firms 15 years or older produce more than half of total Rva, but their contribution to growth is negligible.

\footnotetext{
${ }^{5}$ The growth rate of 1 -year-old firms equals 2 by definition. The growth rate of 2 -year-old firms is above 1 , which is not shown in the figure for two reasons. First, to make the rest of the figure more visible. Second, the calculation assumes that at each year firms operated for the entire year, which is surely not the case for entrants, who may enter any time during the year. As a result, the growth rates calculated for 2 -yearold firms are biased upward, at the same time their weight (mid-point) is biased downward. After all, this affects how growth rates and/or weights are "allocated" between year 1 and year 2 . Since most of the time we analyse the group of 1-4 year-old firms, this has minor impact on the results.

${ }^{6}$ This is different from the findings of analyses on job creation, where older firms have a negative net contribution to employment growth.
} 


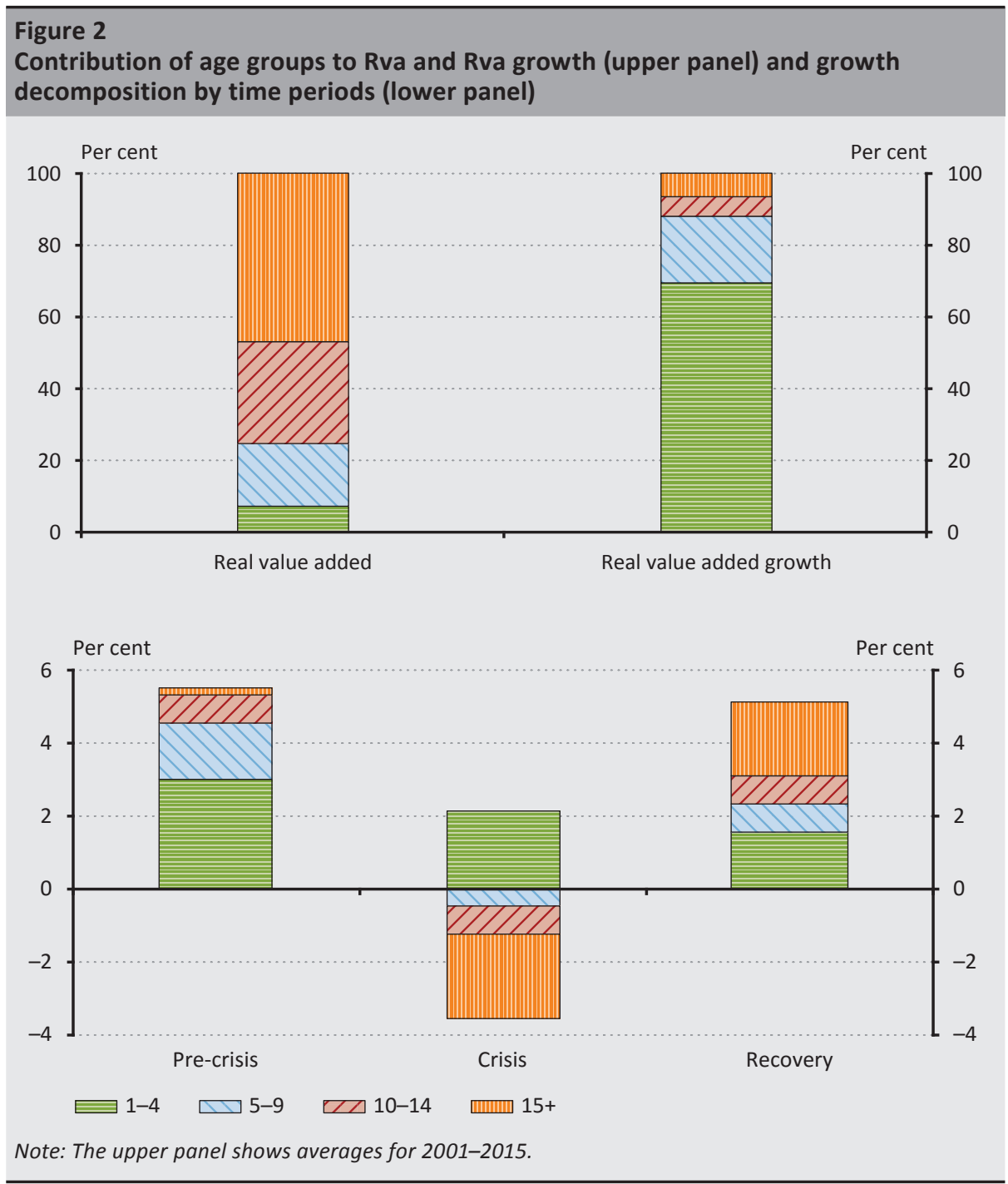

At the same time, the contribution of certain age groups varies according to the business cycle (see lower panel of Figure 2). Young firms do grow even during the crisis - Criscuolo et al. (2014) have similar findings on employment creation. Less firms enter, and their growth rate is lower than during the boom, but they still make a positive contribution to growth. By contrast, the Rva of older firms declines sharply during the crisis, driving the aggregate growth rate well below zero, but then jumps higher during the recovery. Their impact on aggregate growth becomes important because of their large share in Rva, and not necessarily because of their 
stronger cyclicality. ${ }^{7}$ Interestingly, the performance of young firms did not recover in 2013-2015, which is related to the severe setback in firm creation - the entry rate was steeply declining in this period.

To see more details on what happened during the crisis and the recovery, the decomposition of Rva growth is enhanced (see Figure 3 ) by separating gross terms: creation (contribution of firms with positive growth rate) and destruction (contribution of firms with declining Rva) of incumbent firms, entry and exit. When the crisis hit, the decline in the Rva growth rate materialises through all channels. More firms exit, the contribution of entrants falls, and the performance of continuing firms declines as well: gross creation falls and destruction increases, resulting in an overall negative net impact for incumbents. Both entries and exits play an "accelerator" role: during the crisis they not only contribute to the overall slowdown, but their share in gross creation and destruction increases as well. The share of new entrants in gross creation falls from 6.6 per cent to 4.9 per cent during the crisis, while the share of exits in gross destruction on the other hand increases from 7 per cent to 7.9 per cent.

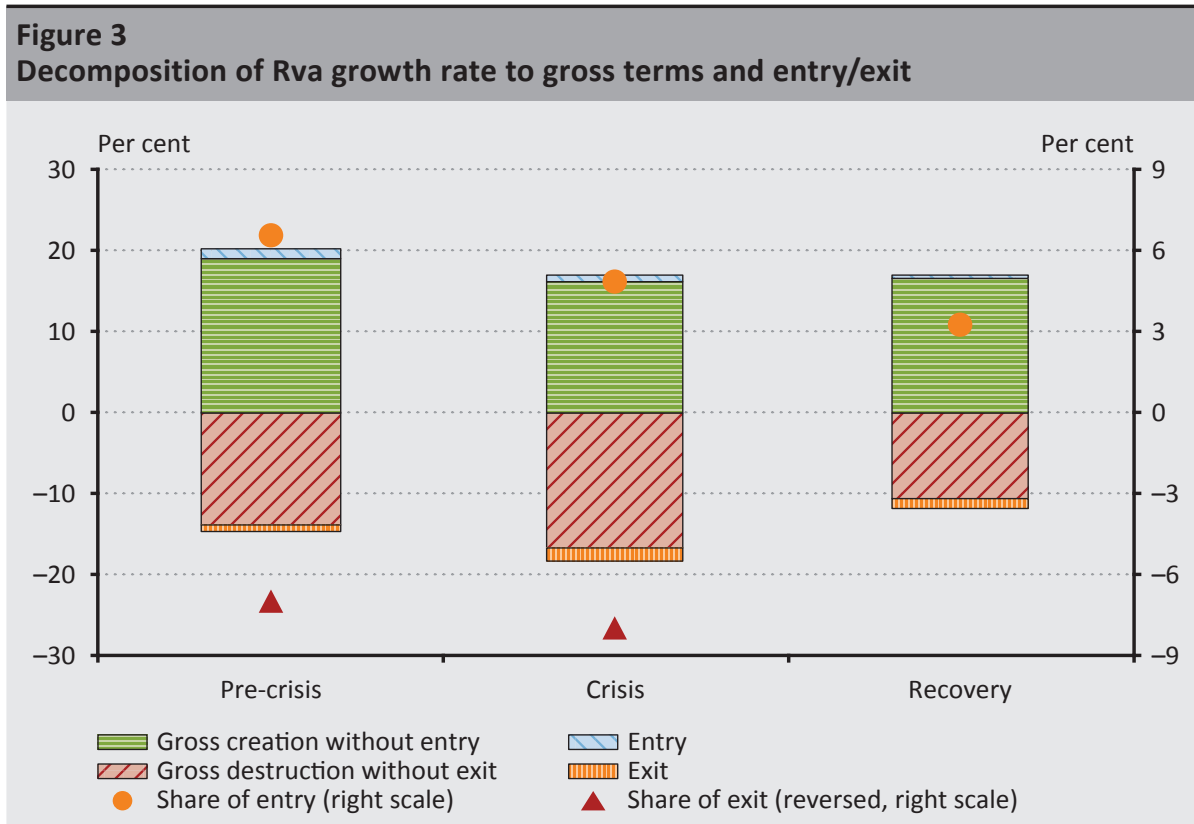

Note: Share of exits for 2013-2015 is not shown because unobserved temporary exits in later years may significantly bias the figure.

\footnotetext{
${ }^{7}$ During the period investigated, a gradual aging of firms is observed, which accelerates because of the crisis. That ageing leads to an increasing weight of older firms in Rva. But the rebound in the older age groups during the recovery is only partially explained by their increasing weight. For simplicity we do not decompose Rva growth further.
} 
The recovery period, instead of being a mirror image of the crisis, has some distinct features. The recovery is driven by less destruction rather than more creation - no improvement is observed in either firm creation or positive growth. Regarding incumbent firms, fewer firms shrink, or the magnitude of decline is smaller, but there is little improvement in terms of positive growth. Another distinct and alarming feature of the recovery is the further decline in the contribution of entries. The decline is observed both in terms of absolute contribution and in terms of share in gross creation - the latter drops to 3.3 per cent, standing at a mere half of the pre-crisis figure. This is in sharp contrast to the behaviour of exits: their contribution to overall growth - as one would expect - decreases during the recovery, while their relative role in gross destruction cannot be judged due to data problems. ${ }^{8}$

Overall, exits seem to behave countercyclically and their impact accelerates during downturn. The evaluation of countercyclical exits is not without ambiguity. On one hand, exits may make productive capacity disappear and the reallocation of production factors can be limited. On the other hand, recessions can induce a cleansing effect through exits by pushing the least productive firms out of the market. To what extent this cleansing effect worked during the Great Recession is an interesting question for future research.

As for entries, we expect this to be procyclical. Entrants do show sign of procyclicality during the recession, but their behaviour during the recovery is rather surprising. The contribution of entrants and more generally young firms has trended downward since the onset of the crisis. The fall in the entry rate was observed in many countries during the Great Recession, and its size and persistence are regarded as exceptional in several countries where long time series are available. ${ }^{9}$ In Hungary, firm creation halted for a very long period, and the entry rate was declining even 8 years after the outbreak of the crisis. Low entry harms growth over the longer term, as falling entries in a given year lowers growth not just in that year, but also in the following ones, through the lower share of dynamic young firms. In this way, the decline in entries induces a persistent slowdown in output. The importance of entries (and exits) and their potential role in prolonging the recovery is recognised not just by empirical studies, but in theoretical model developments as well (Clementi-Palazzo 2016 and Clementi et al. 2017). ${ }^{10}$

\footnotetext{
${ }^{8}$ Exit data for the recovery period is exaggerated. In general, there are many firms in the Hungarian economy, which exit temporarily, and some years later restart operation and reporting financial accounts. Towards the end of the sample the distinction between the two types of exits becomes impossible. Some of the exits categorised as final will turn out to be temporary, and therefore the impact of exits in the recovery period is exaggerated. Still, we find that the role of exits drops during the recovery, which would be even more pronounced, if we were able to measure exits correctly. Because of this issue we do not show the ratio of exits to destruction in the figure.

${ }^{9}$ For the US it is documented by Gomis and Khatiwada (2015), Gourio et al. (2016) or Clementi et al. (2017).

${ }^{10}$ The decline in entry rates and its consequences on corporate investments are documented in Bauer and Endrész (2017).
} 
As young firms are shown to be dynamic and small, the question arises as to whether size or age is more important for growth. Using employment data, Haltiwanger et al. (2006) shows that small firms tend to make a larger contribution to employment creation, but if we control for age, this impact disappears. Apparently, the positive correlation between size and growth is due to the fact, that small firms tend to be younger. Benk - Morvay - Telegdy (2018) reach the same results with Hungarian data. We conduct a similar exercise, regressing Rva growth rates on firm size and age dummies, while controlling for year and sectoral fixed effects. Results partly differ from the findings on employment creation. Larger firms are found to grow faster, with the largest difference between micro firms and the rest (Figure 4). The differences observed between the small, medium and large groups are not significant. If we control for age, i.e. comparing firms of the same age, the average differences - as expected - become even larger (estimated parameters double), at the expense of smaller firms.

During the crisis (lower panel of Figure 4), micro firms' relative performance slightly deteriorates, but in the recovery period there is some reversal, especially for large and medium sized firms.

Estimation results on the impact of age reinforce the previous findings, as growth rates steeply decline with age (Figure 5). Controlling for size has a minor impact on the results. Altogether, age seems to be more influential than size. The comparison of partial $R^{2} s$ of different models leads to the same conclusion (not shown). 


\section{Figure 4 \\ Rva growth by size \\ (coefficients from a regression of Rva growth on size and on age, micro=0)}
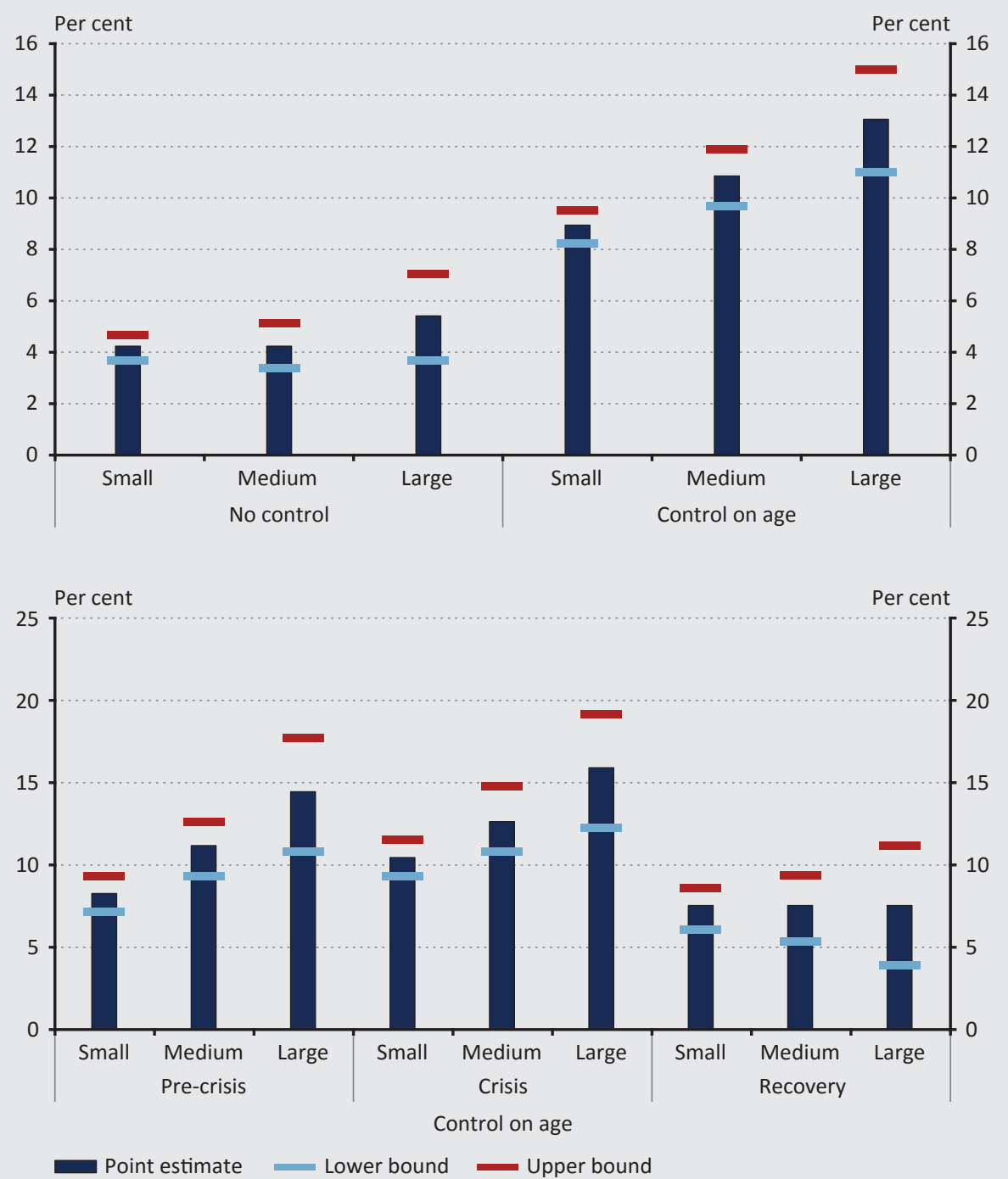

Note: Average (of $t$ and $t-1$ ) Rva weighted linear regression coefficients, micro firms are the control group, with year and 2-digit sectors dummies. Lower and upper bounds are bounds of the 95 per cent confidence interval. 


\section{Figure 5}

Rva growth by age, with and without control of size

(coefficients from a regression of Rva growth on size and on age, 15+=0)
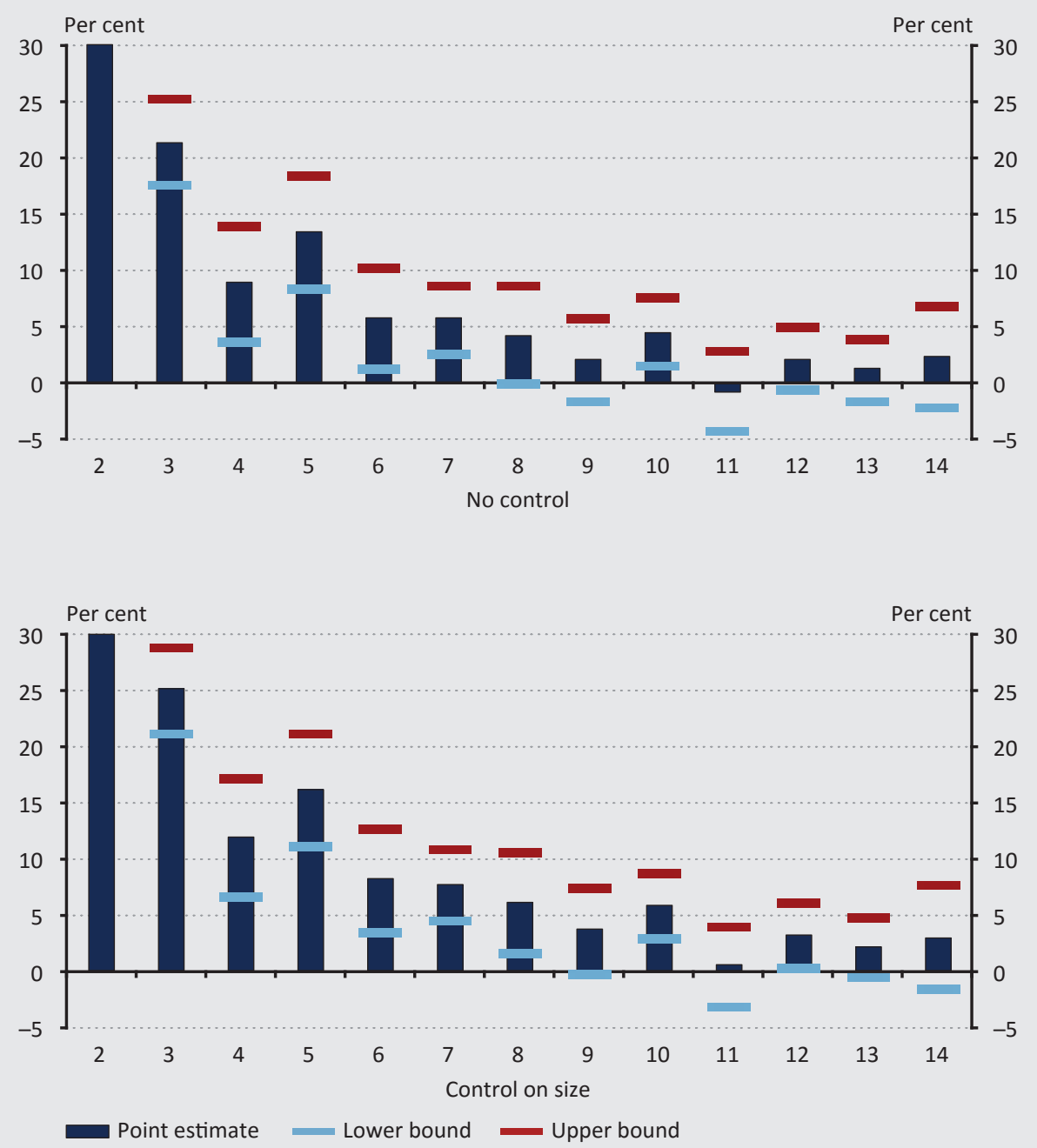

Note: Average Rva weighted linear regression coefficients, $15+$ old firms are the control group, with year and 2-digit sectors dummies. Lower and upper bounds are bounds of the 95 per cent confidence interval. Left axis is truncated at 30 per cent. 


\section{Productivity and age}

In this section, we investigate the relationship between productivity and age, and the effect of entry and exit on productivity. We measure productivity by the labour productivity of firms in logarithm, i.e. by the logarithm of real value added per persons employed. ${ }^{11}$ Aggregate productivity is the employment weighted average of the firm-level (log) productivity. Thus, aggregate productivity can be considered as a geometric mean of firm-level productivity. Labour productivity has the advantage that it is observable opposed to total (or multi-) factor productivity which is an unobservable measure of productivity. The level of productivity is positively correlated with age (Figure 6). While entering (1-year-old) firms have markedly lower labour productivity than older firms, the increase in productivity slows down above about 10 years of age.

The crisis did not change significantly the relationship between age and productivity. We can observe that entering firms have higher productivity in the recovery period (2013-2015) than before. This may be related to self-selection because of the lower entry rate. This phenomenon may also be reflected in the somewhat larger size of entering firms (not shown here).

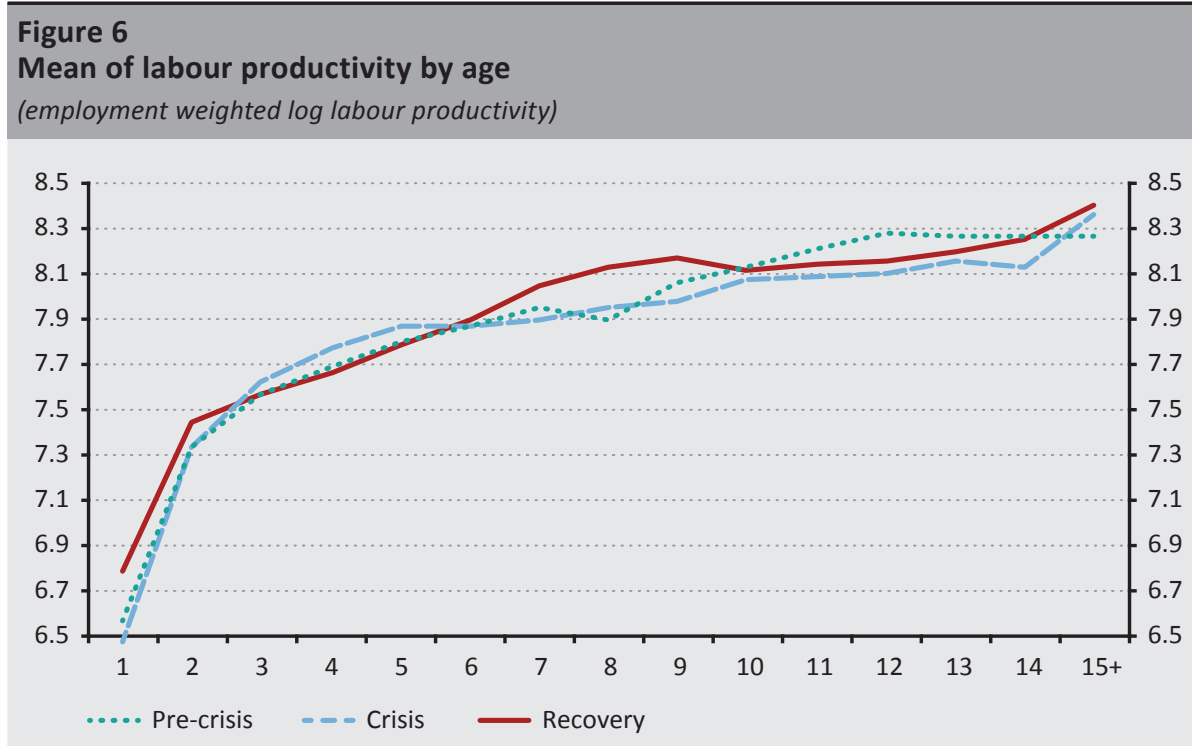

${ }^{11}$ Persons employed is defined in full-time equivalent thus correcting for potential changes in hours worked per person. 
As we have seen, entering firms have lower productivity than existing older firms, and thus the immediate effect of entry on aggregate productivity is negative. This is not the case for exits (Figure 7, upper panel). Exiting firms (those which will exit in the next year) always have lower productivity than existing ones in the same age group. Thus, the effect of exits is always positive on productivity. But the productivity of exiting firms increases with age. Consequently, exiting firms that are 3 years or older (and usually, but not always 2-year-old firms) have higher productivity on average than entering firms. This suggests that the effect of net entries on productivity may be easily negative if the weight of 3-year or older exiting firms is large enough to offset the lower productivity of exiting firms with an age of 1 or 2 years.

As exits can raise the productivity of all age groups, it is a natural question as to how much of the increase in the level of productivity by age is due to exiting. To this end, we calculated the average productivity only for continuers, i.e. firms that have labour productivity both in the previous and in the next year. Thus, entries and exits do not influence the age-productivity relationship in this case. ${ }^{12}$ According to our findings, the increase in productivity by age is very similar to the case where we take all firms into account, only the curve is shifted upwards (Figure 7, lower panel). This means that increasing productivity by age is not the result of exits by lower productivity firms. ${ }^{13}$

We also examine productivity by size. We find that larger firms have higher productivity, which is in line with the results that were documented already in Hungary and in several countries (see e.g. OECD 2017 for international results, and MNB 2015 for Hungary). This is not surprising, as firms which become larger benefit more from economies of scale. As age and size have a positive correlation, we also run a regression where we control for age (and year and 2-digit sectors) to filter out the effect of age on productivity through size. According to our results, larger firms still have higher productivity (Figure 8, upper panel). This means that comparing two firms with equal age, the larger one has higher productivity. We note that controlling for age has smaller importance for productivity than for value added growth (the coefficients change by a smaller amount).

Using regression, we also checked whether the positive relationship between age and productivity remains if we control for size (and year and 2-digit sectors). According to the results, the controls change the coefficients only slightly, and thus productivity increases with age (Figure 8, lower panel).

\footnotetext{
${ }^{12}$ Entry in a broader sense is possible for firms older than 1 year, as log labour productivity can be missing because of zero employment or zero value added.

${ }^{13} \mathrm{~A}$ more detailed analysis of the source of productivity growth would require the study of the effect of reallocation on productivity which is beyond the scope of this paper.
} 


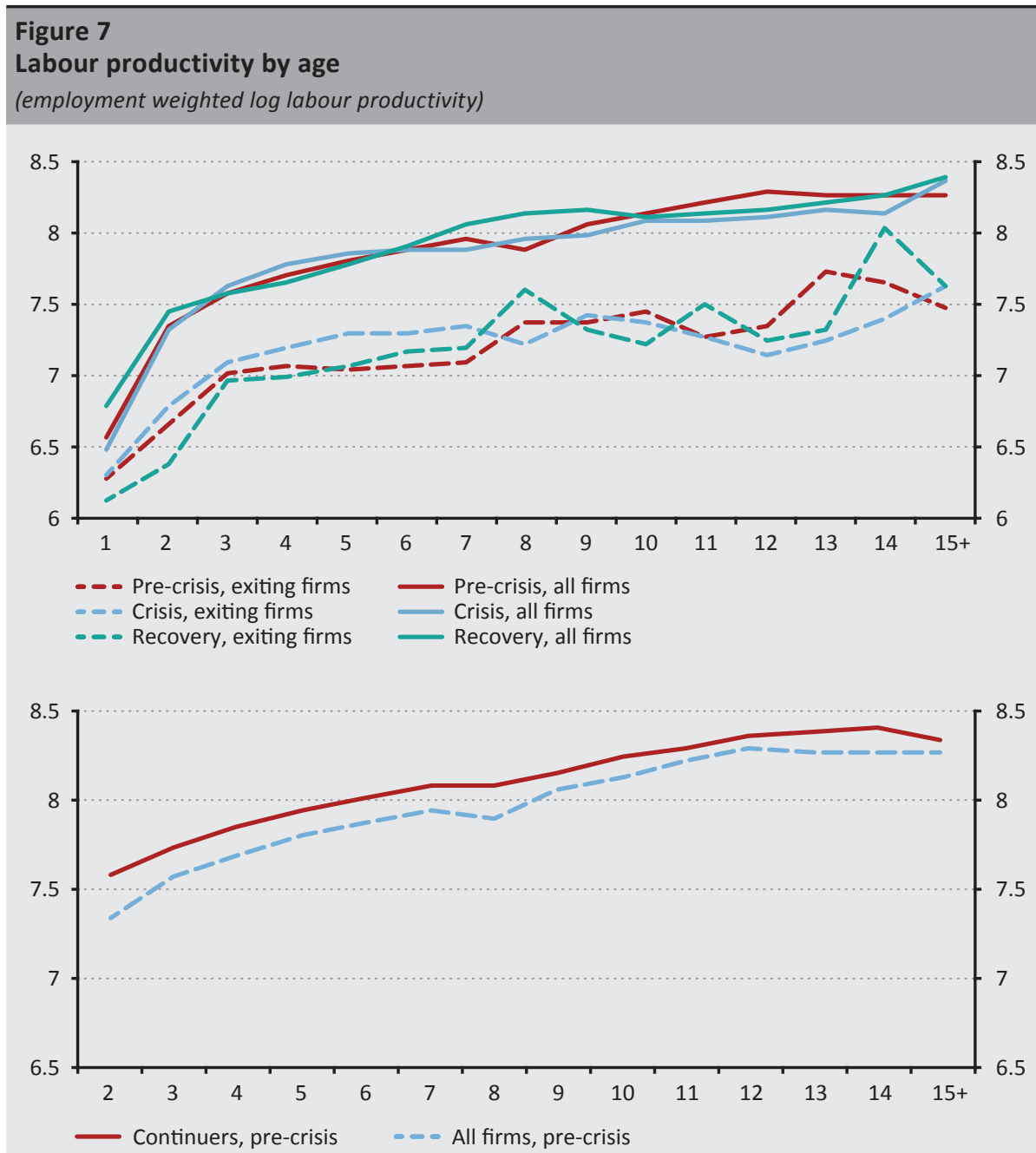

Note: Continuers are firms that have log labour productivity in the previous and in the next year as well. This means that they cannot be entrants or exit in the next year.

We also investigated whether size or age better explains the variance of productivity. According to our results, (based on partial $R^{2} s$ ) the size of a firm is a much important determinant of productivity than the age. 

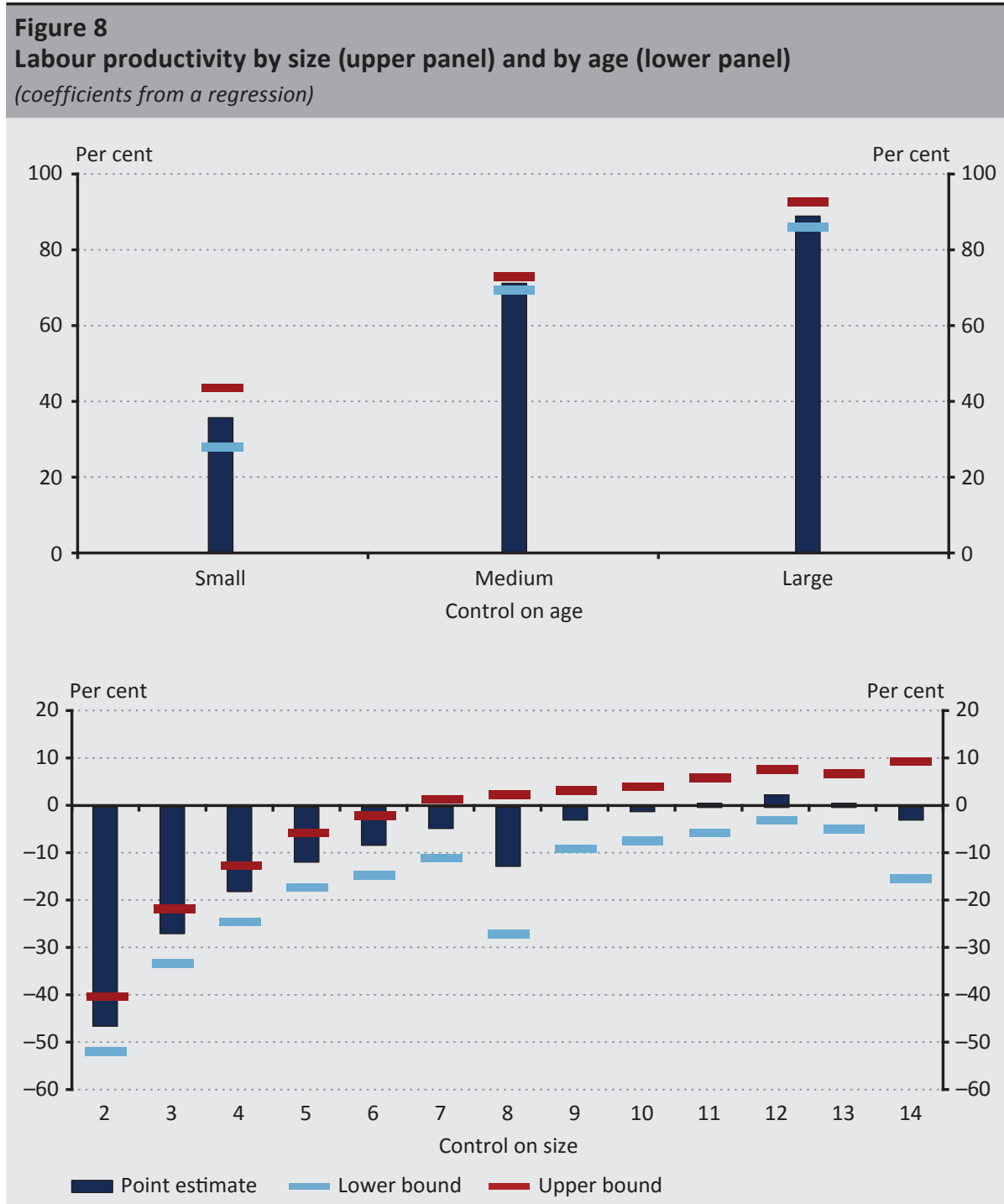

Note: Employment-weighted linear regression coefficients, micro firms are the control group for size, $15+$ old firms are the control group for age, with year and 2-digit sectors dummies. Lower and upper bounds are bounds of the 95 per cent confidence interval. 


\section{Export growth and age}

Exports are a fundamental indicator of firm performance: usually more productive firms engage in exports. Exports are also important from an aggregate point of view as Hungary is a very open economy, and exports are a dominant source of economic growth. In the following, we study the exporting activity of firms and its change with firm age. Firm-level export growth is defined the same way as in the case of value added, using the so-called mid-point growth. In this section, entry and exit is (re)defined in terms of entering to/exiting from export markets.

The relationship between age and export growth is very similar to value added growth (Figure 9). Young firms grow much faster than older firms, and the growth rate decreases at a slower pace at higher ages. The main difference is that in the case of export growth, old firms (older than 10) also show positive growth as opposed to value added growth, which is very close to zero. This can be explained by the fact that many firms are able to enter to export markets at a later age only, when they reach the necessary level of productivity and competitiveness. The sheer size and growth of export markets and the special properties of exporting activity may also force firms to remain innovative and dynamic even in the later part of their life.

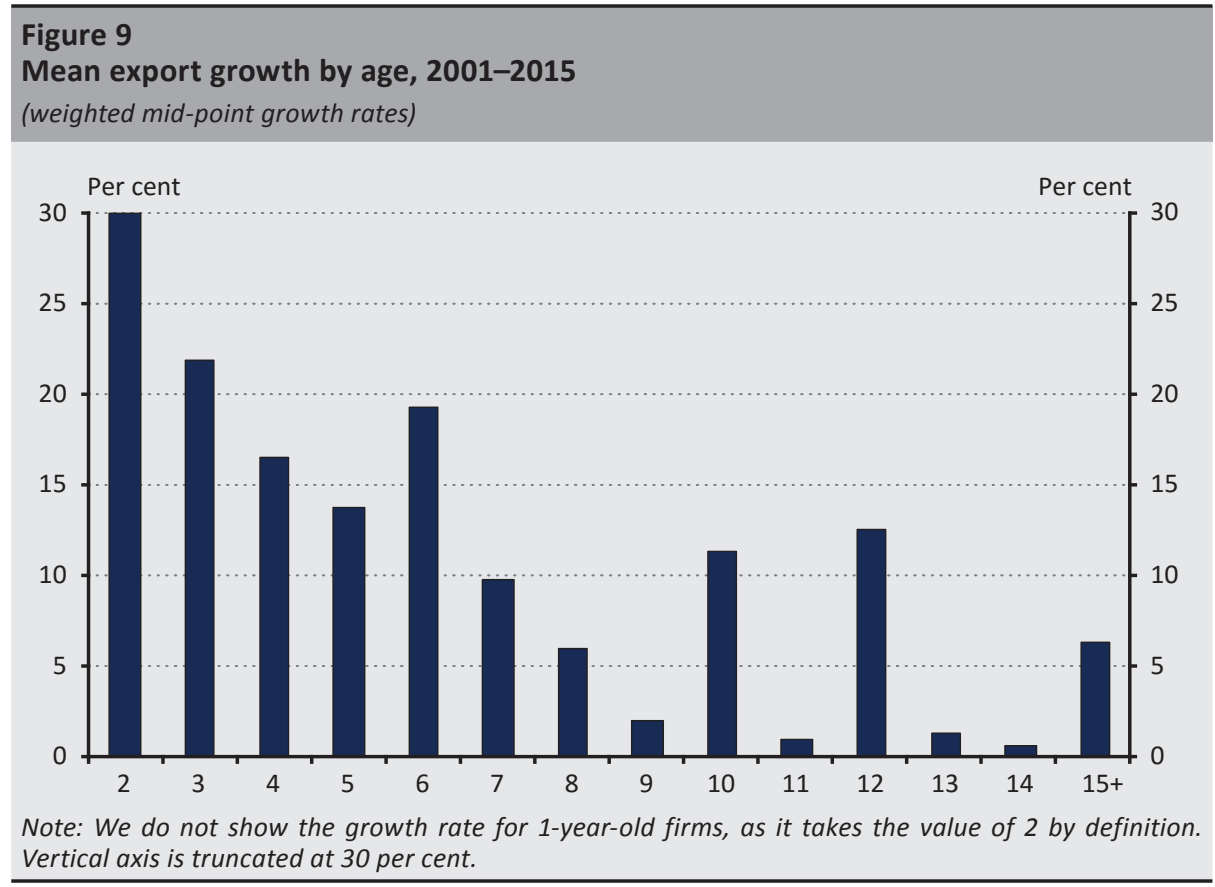


The importance of various age groups in export growth depends not only on their growth rates, but also on their weights in exports. Consequently, we decompose export growth to the contribution of age groups. According to our results, young firms play a significantly smaller role in export growth than in value added growth (Figure 10, upper panel). Older firms dominate even before the crisis when average age was significantly lower than later. During the crisis, not only the youngest firms show a positive contribution but even the oldest firms. After the crisis, the youngest firms' contribution can be considered marginal. The result that older firms are more important in export growth than in value added growth is closely related to the above shown fact that older firms show positive export growth. It is worth noting that this is not the consequence of disproportionately high weights of older firms as the weights are very similar to the ones for value added (not shown here).

Beyond the role of age, we would like to show the importance of the extensive margin, i.e. entry and exit on export growth. To this end, we decompose aggregate export growth into the contribution of four groups of firms. In the first group (called gross creation without entry), there are the firms that export in the previous year, so they are not entrants, and show positive growth. The second group (called gross destruction without exit) consists of firms that export in the current year (so they are not exiting) but show negative growth. The third and fourth groups are the entrants and exiting firms, respectively. Figure 10 (lower panel) shows the decomposition and the share of contribution of entrants to gross creation. ${ }^{14}$ The most important conclusion is that the contribution of entries decreased markedly after the crisis in absolute terms and compared to gross creation as well. Another observation is that the deceleration of export growth during the crisis period (2008-2012) is driven by smaller gross creation and larger gross destruction of continuing firms, while the changing contribution of entries or exits is less pronounced. Recovery is driven by smaller gross destruction including the decreasing contribution of exits. The shrinking importance of exits in the recovery period can be partly related to the lower entry rate as young firms have higher exit rates. In the recovery, similarly to value added growth, gross creation did not play a role, even if we disregard the falling entry rate.

We also examine export growth by size (for the analysis of exporting activity by firm size in Hungary, see e.g. MNB 2017, for the export growth and size relationship in France, see e.g. Berthou and Vicard 2015). Even if we control for age, larger firms have a higher export growth rate (Figure 11, upper panel). It is also worth noting that differences due to size (e.g. micro vs. small firms) are much larger than in the case of value added growth.

\footnotetext{
${ }^{14}$ It is important that we show the contribution of entries compared to gross creation and not the contribution of net entries to overall growth. Net entries and even overall growth can be negative, so the share is not meaningful. Gross creation and entries are always positive, and entries are part of gross creation, so the share in this case is meaningful.
} 


\section{Figure 10 \\ Decomposition of exports growth by age groups (upper panel) and to growing, shrinking, entering and exiting firms (lower panel) \\ (weighted growth rates)}
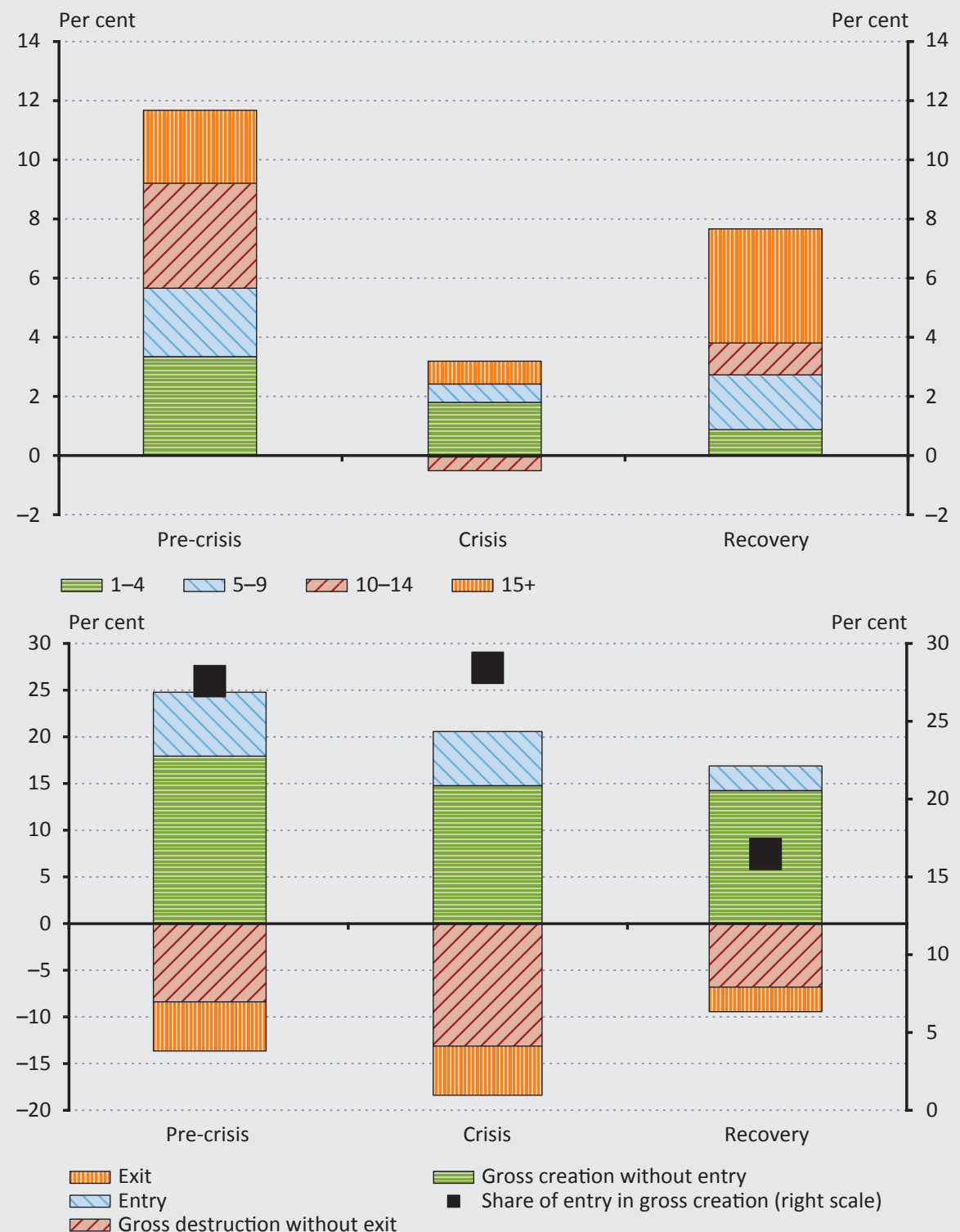

Note: Entering (exiting) firms are defined as firms that start (cease) exporting in the current year. 
We also checked using regression whether the relationship between age and export growth remains if we control for size. According to the results (Figure 11, lower panel) export dynamics decrease with age even after controlling for size. We also investigated whether age or size is more important in explaining export growth. We found (based on partial $R^{2} s$ ) that age is more important than size, but size is relatively more important in this case compared to value added growth.

\section{Figure 11 \\ Export growth by size (upper panel) and by age (lower panel) \\ (coefficients from a regression of exports growth on size and on age, micro $=0$ and $15+=0$, respectively)}
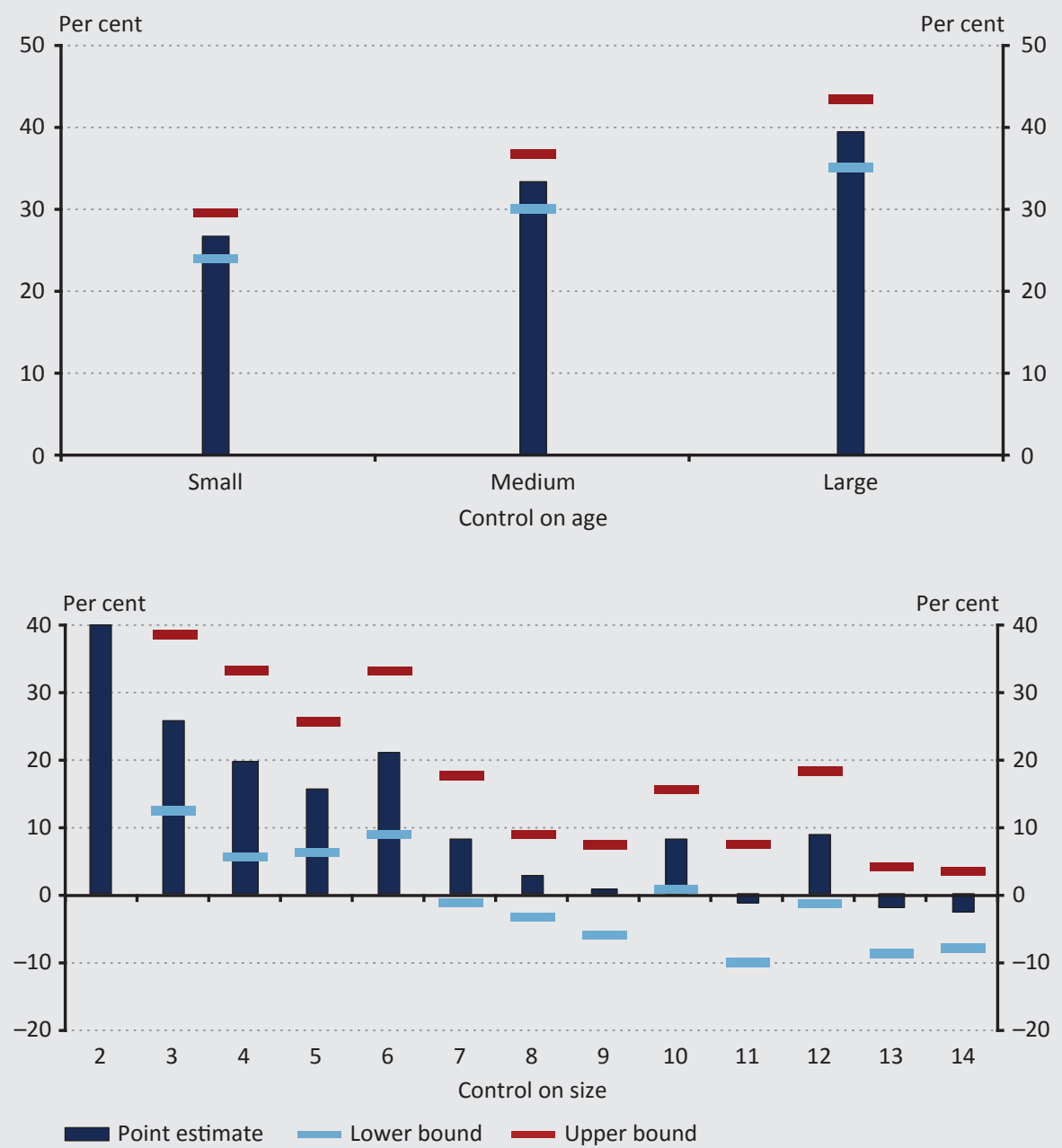

Note: Average (of $t$ and $t-1$ ) exports weighted linear regression coefficients, micro firms are the control group in the case of size, and 15+ old firms are the control group for age, with year and 2-digit sectors dummies. Lower and upper bounds are bounds of the 95 per cent confidence interval. 


\section{Lending and age}

Bank lending and age are expected to be intertwined because of the changes of supply and demand factors during a firm's life cycle phases. ${ }^{15}$ Young firms tend to experience high growth and accordingly to have high funding needs. But as they are young and small, exposed to large risk (high failure rate) and often lack collateralisable assets, their creditworthiness is low, and the bank credit supply is thus limited. As they grow, become more profitable and less risky, banks become more willing to finance them. As they grow even older, their growth slows down, lowering their financing needs, while their ability to produce sufficient internal funds is elevated. In sum, we expect an inverted U-shaped relationship between age ${ }^{16}$ and use of bank loans, where supply plays a role mainly on the upward sloping part.

Changes in bank borrowing over time are also of interest, as the crisis triggered changes in bank supply, with a potentially large impact on aggregate growth.

The analysis of bank borrowing and the age of firm differs from the previous analyses. The available credit registry data constrains the analysis, as the outstanding value of loans is not available for most of the period under examination. Therefore, instead of loan amounts and the related growth rates we analyse the probability of firm-bank relationships, differentiating between the probability of taking out a new loan or having bank loan. Even in that case full coverage is ensured only from 2005, shortening the time period covered to 2005-2015. While we restrict the analysis to certain institutions (banks, foreign subsidies and leasing companies) and certain types of contracts (loans, credit lines, leasing, purchase of receivables), the qualitative results are the same if we add special financial institutions and cooperatives or other type of contracts (guarantees, etc.). Results for the latter are not reported.

Looking only at the probability of taking out or having a loan, we detect a positive correlation with age (Figure 12). The older a firm is, the more likely it has loan or takes out a new loan. There is a steady increase in probability up to the age of 5 or 6 , which is likely to be driven by the changing supply. This is the age where growth starts slowing down, as seen in Figure 1 (lower panel). Before the crisis, close to 30 per cent of mature and older firms (older than 5 years) had a bank loan, while about 15 per cent of them took out a new loan per year on average. Following the outbreak of the crisis, there is a huge drop in the use of bank loans. The probabilities decline even during the recovery. The youngest and oldest firms are more affected. Whether it is mainly due to supply or demand factors, needs further investigation.

\footnotetext{
${ }^{15}$ See e.g. Castro et al. (2014) and Bulan and Yan (2010) for discussion on the link between the life-cycle and the capital structure decisions of firms.

${ }^{16}$ Age is often used as a proxy of life-cycle phases.
} 


\section{Figure 12}

Probability of taking out a new loan (upper panel) and of having a loan (lower panel) by age and time periods
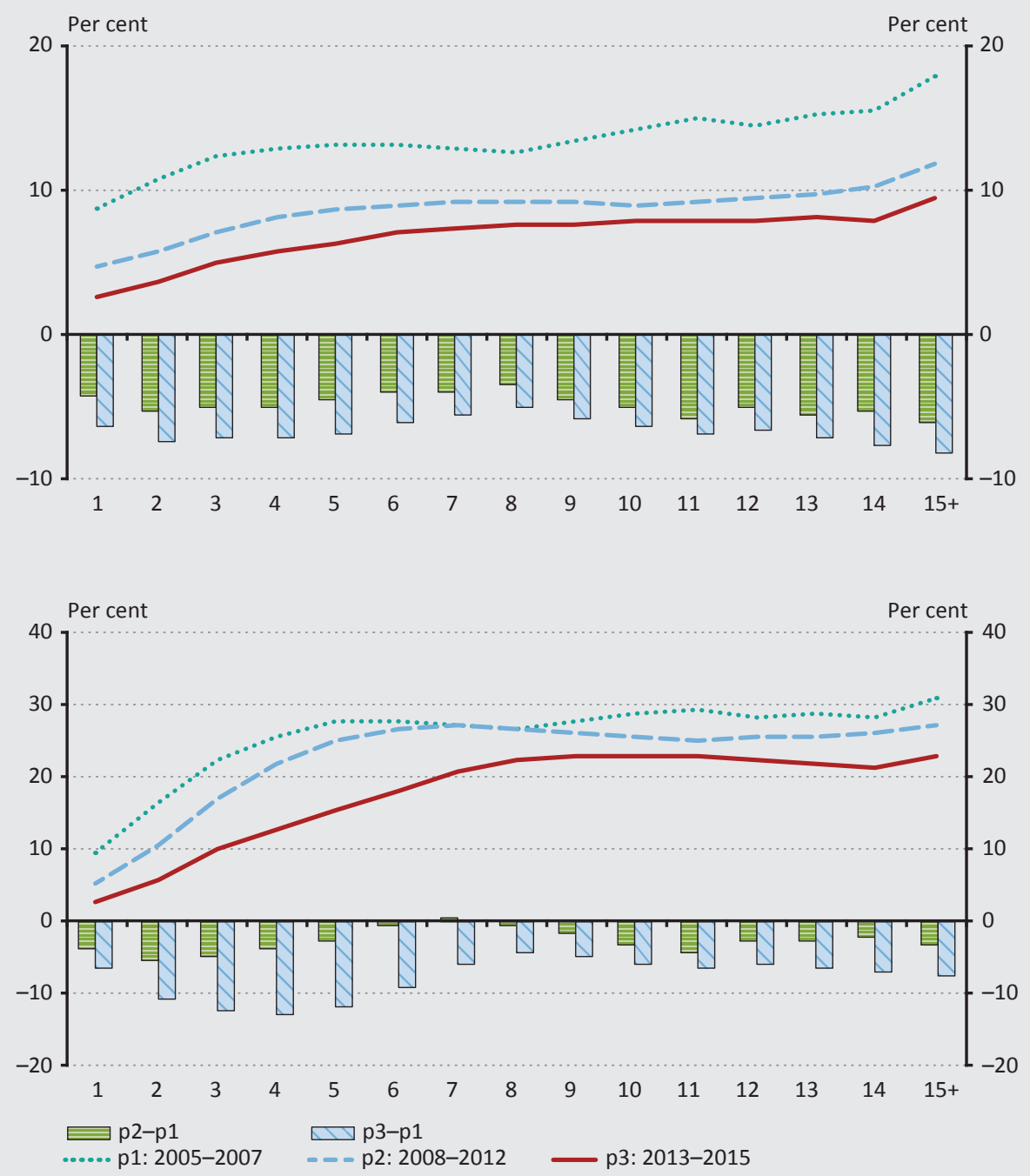

Note: Unweighted probabilities. p1, p2 and p3 denote the periods of 2005-2007, 2008-2012 and 20132015, respectively, while p2-p1, and p3-p1 denote the differences between time periods.

The age-bank borrowing correlation changes slightly when regression is conducted instead of calculating average probabilities, and follows the expected inverted U-shape (see Figure 13). This is even more so the case when we control for the size of the firm. 

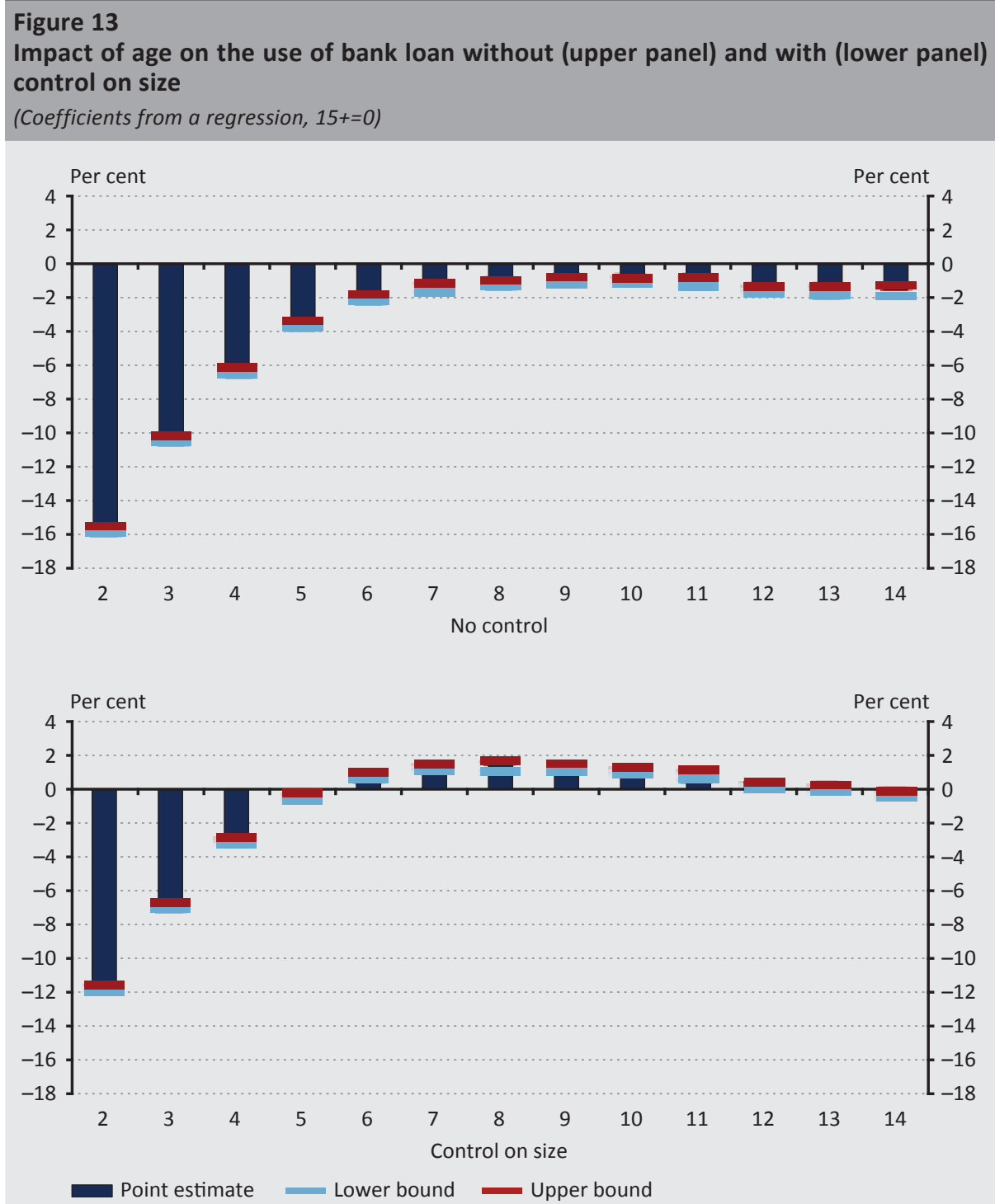

Note: Unweighted regression of a linear probability model of having a bank loan. Control group for age is 15+. Year and 2-digit sector dummies are included. Lower and upper bounds are bounds of the 95 per cent confidence interval.

The probability of using bank loans increases with the size of the firm as well. This correlation does not change much even if we compare firms of the same age (control for age as well). Apparently, size has a large impact on borrowing. Micro firms are the most disadvantaged: their probability of having a loan is 30-40 percentage point lower than that of larger firms. The medium and large group is almost identical regarding their bank loan use (Figure 14). 
Considering the question whether age or size matter, we have seen that both do, but by comparing the partial $R^{2} s$ we find that size had much greater explanatory power than age.

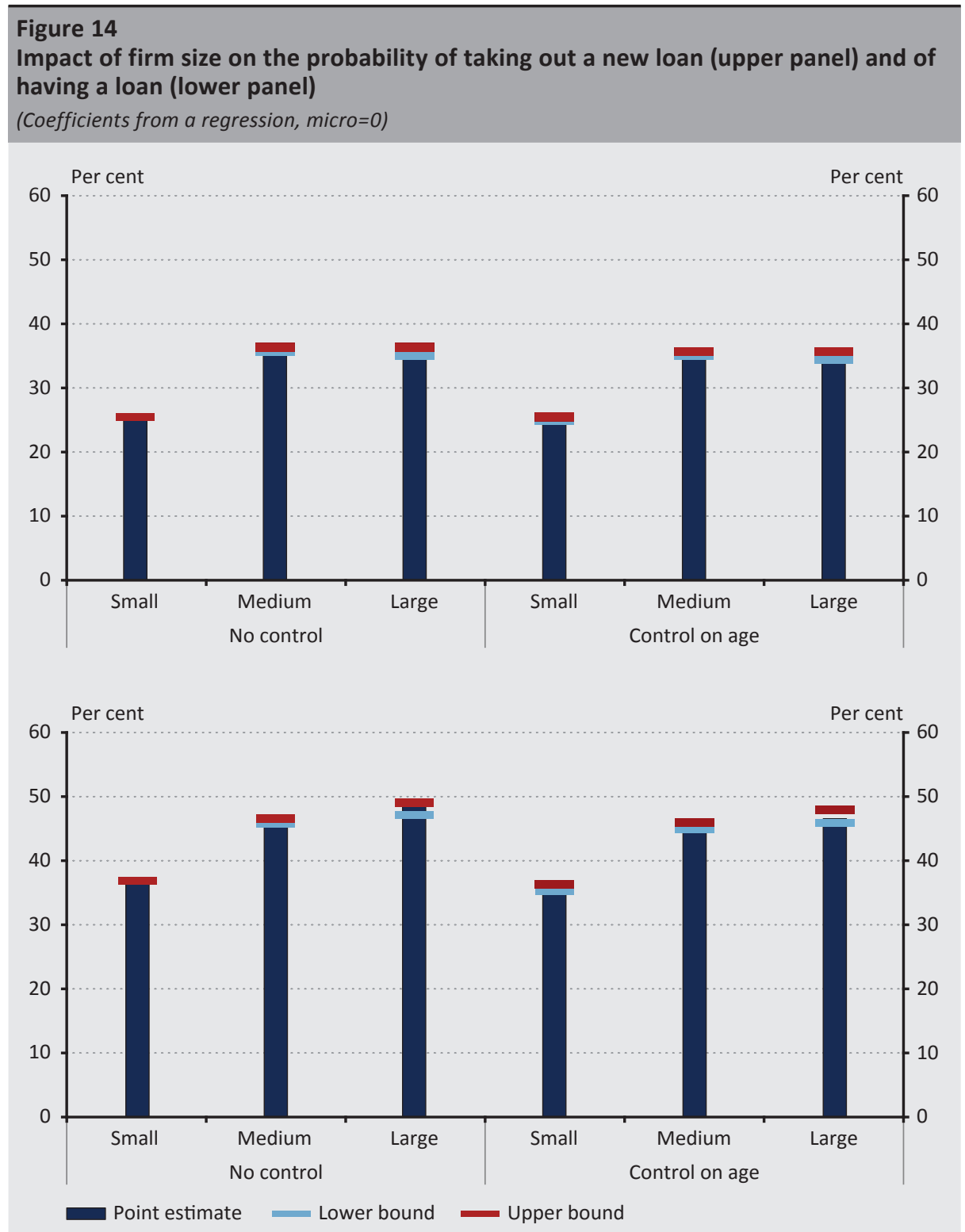

Note: Unweighted regression of a linear probability model of having a bank loan. Control group for size is the group of micro firms. Year and 2-digit sector dummies are included. Lower and upper bounds are bounds of the 95 per cent confidence interval. 


\section{Conclusions}

We documented several stylised facts in this paper concerning firm dynamics in the Hungarian economy, the debate on age versus size and the adjustments observed during the recent financial crisis.

We find that young firms tend to be small and that size and age are highly correlated. Young firms grow faster, but at the same time they frequently exit and their performance is dispersed. Age is more important than size in explaining the dynamics of firms.

The high growth of young firms (1-4 year) makes them important for aggregate growth as well: despite their overall small share in output, almost 70 per cent of aggregate growth is attributed to this group. The story is somewhat different for exports, where older firms remain more dynamic, and therefore their contribution to aggregate exports growth is much larger as well.

When we examine levels instead of growth rates, e.g. the level of productivity and the probability of having a bank loan, we find that these are mainly determined by the size instead of the age of the firm. As firms age they become more creditworthy and more productive, but size explain more of the cross-firm variation.

During the crisis the adjustment was heterogeneous along age and size. The fall in real value added growth during the crisis and the rise during recovery were dominated by the changing performance of older firms, while young firms' contribution to growth remained positive. The adjustment took place both on the extensive and intensive margin - fewer firms entered, more exited, creation weakened, and destruction increased. Heterogeneity is observed in the loan market as well: the decrease in lending affected younger and older firms more severely compared to middle-aged firms, which may have different reasons in terms of supply and demand at the two ends of the age distribution.

Interestingly, the recovery seems to be dominated by the lower-end of the distribution of firm population: destruction eased and fewer firms exited, but there was no recovery in gross creation. The contribution of firm entries kept falling even during the recovery period, which applies even to export markets. Given the importance of young firms in growth, this behaviour of entry must have contributed to the sluggish, weak recovery. Both the willingness or ability of firms to grow and to enter were weakened. Whether the reason is a general increase in uncertainty, changes in regulation (regarding entry) or the still-effective financing constraints presents an interesting question for future research. 
This paper is descriptive in nature. Causal analysis and deeper exploration of some issues - e.g. the reasons of the prolonged fall in entry rates, the impact of bank supply shocks - are left for future research. Another important extension would be to update calculations on reallocation as well and to analyse creative destruction during the crisis.

\section{References}

Aghion, P. - Akcigit, U. - Howitt, P. (2014): What Do We Learn from Schumpeterian Growth Theory? In: Handbook of Economic Growth, Elsevier, ed. 1, vol. 2, no. 2.

Andersson, L.F. (2006): Firm demography and aggregate productivity growth. ITPS, Swedish Institute for Growth Policy Studies.

Bauer, P. - Endrész, M. (2017): Corporate Investment in Hungary - Stylised facts on Micro Data. MNB Occasional Papers 131.

Bartelsman, E. - Haltiwanger, J. - Scarpetta, S. (2004): Microeconomic evidence of creative destruction in industrial and developing countries. World Bank Policy Research Working Paper Series, number 3464.

Békés, G. - Halpern, L. - Muraközy, B. (2011): A teremtő rombolás szerepe a vállalati termelékenység alakulásában Magyarországon (The role of creative destruction in the development of corporate productivity in Hungary). Közgazdasági Szemle, 58(2): 111-132.

Berthou, A. - Vicard, V. (2015): Firms' Export Dynamics: Experience Versus Size. The World Economy, Wiley Blackwell, 38(7): 1130-1158. https://doi.org/10.1111/twec.12221

Benk, Sz. - Morvay, E. - Telegdy, Á. (2018): KKV-k és nagyvállalatok: hogyan járulnak hozzá a munkahelyteremtéshez? (SMEs and Big Firms: How Do They Contribute to Job Creation?) Szakmai cikk (Article), Magyar Nemzeti Bank. https://www.mnb.hu/letoltes/benk-morvaytelegdy-kkv-k-es-nagyvallalatok-hogyan-jarulnak-hozza-a-munkahelyt-mnb-honlapra.pdf

Brown, J.D. - Earle, J.S. (2008): Understanding the Contributions of Reallocation to Productivity Growth: Lessons from a Comparative Firm-Level Analysis. IZA Discussion Paper. No. 3683. https://doi.org/10.17848/wp08-141

Bulan, L. - Yan, Z. (2010): Firm Maturity and the Pecking Order Theory. International Journal of Business and Economics, 9(3): 179-200. https://doi.org/10.2139/ssrn.1760505

Castro, P. - Tascon, M.T. - Tapia, B.A. (2014): The role of life cycle on the firm's capital structure. Pecvnia, no. 19. 
Clementi, G.L. - Palazzo, B. (2016): Entry, Exit, Firm Dynamics, and Aggregate Fluctuations. American Economic Journal: Macroeconomics, 8(3): 1-41. https://doi.org/10.1257/ mac. 20150017

Clementi, G.L. - Palazzo, B. - Wu, P. (2017): Firm Demographics and the Great Recession. Manuscript. Version: August 23.

Criscuolo, C. - Gal, P.N. - Menon, C. (2014): The Dynamics of Employment Growth: New Evidence from 18 countries. CEP Discussion Paper No 1274.

Davis, S. - Haltiwanger, J. - Schuh, S. (1996): Small Business and Job Creation: Dissecting the Myth and Reassessing the Facts. Small Business Economics, Springer, 8(4): 297-315. https://doi.org/10.1007/BF00393278

Gomis, R.M. - Khatiwida, S. (2017): Firm dynamics and business cycle: What doesn't kill you makes you stronger. IHEID WP No 03.

Gourio, F. - Messer, T. - Siemer, M. (2016): Firm Entry and Macroeconomic Dynamics: A State-Level Analysis. American Economic Review: Papers \& Proceedings, 106(5): 214218. https://doi.org/10.1257/aer.p20161052

Haltiwanger, J. - Jarmin, R.S. - Miranda, J. (2013): Who creates jobs? Small versus large versus young. The Review of Economics and Statistics, 95(2): 347-361. https://doi.org/ 10.1162/REST_a_00288

Haltiwanger, J. - Jarmin, R.S. - Kulick, R. - Miranda, J. (2016): High Growth Young Firms: Contribution to Job, Output and Productivity Growth. Center for Economic Studies Research Papers. CES 16-49. November.

López-Garcia, P. - Puente, S. (2006): Business Demography in Spain: Determinants of Firm Survival. Banco de España, Documentos de Trabajo, No. 0608. https://doi.org/10.2139/ ssrn.901153

MNB (2015): Growth Report. Chapter 3. Magyar Nemzeti Bank, Budapest.

MNB (2017): Growth Report. Chapter 2. Magyar Nemzeti Bank, Budapest.

OECD (2017): OECD Compendium of Productivity Indicators 2017. 


\section{Appendix}

\begin{tabular}{|c|c|c|c|c|c|c|}
\hline \multicolumn{7}{|c|}{$\begin{array}{l}\text { Table } 1 \\
\text { Regression results }\end{array}$} \\
\hline \multirow{2}{*}{$\begin{array}{c}\text { Dependent } \\
\text { variable }\end{array}$} & \multicolumn{6}{|c|}{ Rva growth } \\
\hline & full sample & full sample & pre-crisis & crisis & recovery & full sample \\
\hline age $=2$ year & & $\begin{array}{l}1.023 * * * \\
{[0.0233]}\end{array}$ & $\begin{array}{l}1.022 * * * \\
{[0.0368]}\end{array}$ & $\begin{array}{l}1.070 * * * \\
{[0.0424]}\end{array}$ & $\begin{array}{l}0.987 * * * \\
{[0.0304]}\end{array}$ & $\begin{array}{c}0.982 * * * \\
{[0.0233]}\end{array}$ \\
\hline age $=3$ year & & $\begin{array}{l}0.249 * * * \\
{[0.0198]}\end{array}$ & $\begin{array}{l}0.295^{* * *} \\
{[0.0256]}\end{array}$ & $\begin{array}{c}0.237 * * * \\
{[0.0391]}\end{array}$ & $\begin{array}{c}0.177^{* * *} \\
{[0.0273]}\end{array}$ & $\begin{array}{l}0.214 * * * \\
{[0.0194]}\end{array}$ \\
\hline age $=4$ year & & $\begin{array}{l}0.118 * * * \\
{[0.0274]}\end{array}$ & $\begin{array}{l}0.190 * * * \\
{[0.0256]}\end{array}$ & $\begin{array}{c}0.0865 \\
{[0.0588]}\end{array}$ & $\begin{array}{c}0.0371 \\
{[0.0560]}\end{array}$ & $\begin{array}{c}0.0876 * * * \\
{[0.0259]}\end{array}$ \\
\hline age $=5$ year & & $\begin{array}{l}0.160 * * * \\
{[0.0261]}\end{array}$ & $\begin{array}{l}0.229 * * * \\
{[0.0431]}\end{array}$ & $\begin{array}{c}0.0797 * * \\
{[0.0330]}\end{array}$ & $\begin{array}{l}0.183 * * \\
{[0.0721]}\end{array}$ & $\begin{array}{l}0.134 * * * \\
{[0.0258]}\end{array}$ \\
\hline age $=6$ year & & $\begin{array}{c}0.0805 * * * \\
{[0.0234]}\end{array}$ & $\begin{array}{l}0.141^{* * *} \\
{[0.0445]}\end{array}$ & $\begin{array}{l}0.0427 * \\
{[0.0237]}\end{array}$ & $\begin{array}{c}0.0225 \\
{[0.0304]}\end{array}$ & $\begin{array}{l}0.0574 * * \\
{[0.0228]}\end{array}$ \\
\hline age $=7$ year & & $\begin{array}{c}0.0767 * * * \\
{[0.0162]}\end{array}$ & $\begin{array}{l}0.114^{* * *} \\
{[0.0293]}\end{array}$ & $\begin{array}{l}0.0474 * \\
{[0.0248]}\end{array}$ & $\begin{array}{c}0.0645 * * * \\
{[0.0241]}\end{array}$ & $\begin{array}{c}0.0559 * * * \\
{[0.0157]}\end{array}$ \\
\hline age $=8$ year & & $\begin{array}{c}0.0596 * * * \\
{[0.0225]}\end{array}$ & $\begin{array}{c}0.108 * * * \\
{[0.0388]}\end{array}$ & $\begin{array}{c}0.0681 * * * \\
{[0.0216]}\end{array}$ & $\begin{array}{l}-0.0329 \\
{[0.0461]}\end{array}$ & $\begin{array}{l}0.0421^{*} \\
{[0.0221]}\end{array}$ \\
\hline age $=9$ year & & $\begin{array}{l}0.0348^{*} \\
{[0.0193]}\end{array}$ & $\begin{array}{c}0.0943 * * * \\
{[0.0219]}\end{array}$ & $\begin{array}{l}-0.0422 \\
{[0.0566]}\end{array}$ & $\begin{array}{c}0.0466 * * \\
{[0.0182]}\end{array}$ & $\begin{array}{c}0.0205 \\
{[0.0188]}\end{array}$ \\
\hline age $=10$ year & & $\begin{array}{c}0.0572 * * * \\
{[0.0154]}\end{array}$ & $\begin{array}{c}0.0771 * * * \\
{[0.0233]}\end{array}$ & $\begin{array}{l}0.103 * * \\
{[0.0402]}\end{array}$ & $\begin{array}{c}0.0404 * * \\
{[0.0165]}\end{array}$ & $\begin{array}{c}0.0447 * * * \\
{[0.0154]}\end{array}$ \\
\hline age $=11$ year & & $\begin{array}{c}0.003 \\
{[0.0181]}\end{array}$ & $\begin{array}{c}0.0416 \\
{[0.0269]}\end{array}$ & $\begin{array}{c}-0.0598 * \\
{[0.0363]}\end{array}$ & $\begin{array}{c}0.0526 * * \\
{[0.0208]}\end{array}$ & $\begin{array}{c}-0.00827 \\
{[0.0179]}\end{array}$ \\
\hline age $=12$ year & & $\begin{array}{c}0.0313^{* *} \\
{[0.0145]}\end{array}$ & $\begin{array}{c}0.0504 * * \\
{[0.0236]}\end{array}$ & $\begin{array}{l}0.0408 * \\
{[0.0227]}\end{array}$ & $\begin{array}{l}0.0393 * \\
{[0.0211]}\end{array}$ & $\begin{array}{c}0.021 \\
{[0.0144]}\end{array}$ \\
\hline age $=13$ year & & $\begin{array}{c}0.0199 \\
{[0.0139]}\end{array}$ & $\begin{array}{l}0.0392 * \\
{[0.0234]}\end{array}$ & $\begin{array}{c}0.0268 \\
{[0.0171]} \\
\end{array}$ & $\begin{array}{l}0.00362 \\
{[0.0239]} \\
\end{array}$ & $\begin{array}{c}0.0115 \\
{[0.0139]}\end{array}$ \\
\hline age $=14$ year & & $\begin{array}{c}0.029 \\
{[0.0235]}\end{array}$ & $\begin{array}{c}0.0568 \\
{[0.0377]}\end{array}$ & $\begin{array}{l}0.00488 \\
{[0.0212]} \\
\end{array}$ & $\begin{array}{c}0.0164 \\
{[0.0290]}\end{array}$ & $\begin{array}{c}0.0227 \\
{[0.0235]}\end{array}$ \\
\hline size = small & $\begin{array}{c}0.0418^{* * *} \\
{[0.0028]}\end{array}$ & $\begin{array}{c}0.0887 * * * \\
{[0.0034]}\end{array}$ & $\begin{array}{c}0.0830 * * * \\
{[0.0051]}\end{array}$ & $\begin{array}{c}0.103 * * * \\
{[0.0057]}\end{array}$ & $\begin{array}{c}0.0749 * * * \\
{[0.0066]}\end{array}$ & \\
\hline size $=$ medium & $\begin{array}{c}0.0421^{* * *} \\
{[0.0045]}\end{array}$ & $\begin{array}{c}0.108 * * * \\
{[0.0058]}\end{array}$ & $\begin{array}{l}0.110 * * * \\
{[0.0089]}\end{array}$ & $\begin{array}{c}0.128 * * * \\
{[0.0101]}\end{array}$ & $\begin{array}{c}0.0741 * * * \\
{[0.0106]}\end{array}$ & \\
\hline size $=$ large & $\begin{array}{c}0.0535^{* * *} \\
{[0.0087]}\end{array}$ & $\begin{array}{l}0.130 * * * \\
{[0.0103]}\end{array}$ & $\begin{array}{c}0.143 * * * \\
{[0.0172]}\end{array}$ & $\begin{array}{l}0.158 * * * \\
{[0.0173]}\end{array}$ & $\begin{array}{c}0.0747 * * * \\
{[0.0180]}\end{array}$ & \\
\hline Observations & $3,867,153$ & $3,867,153$ & $1,491,393$ & $1,455,747$ & 920,013 & $3,867,153$ \\
\hline R-squared & 0.018 & 0.061 & 0.061 & 0.075 & 0.053 & 0.057 \\
\hline
\end{tabular}

Note: Robust standard errors in brackets. ${ }^{* * *} p<0.01,{ }^{* *} p<0.05, * p<0.1$. 2-digit industry and year fixed effects are included. Control group for age is $15+$, for size is micro firms. 


\section{Table 1}

Regression results - cont.

\begin{tabular}{|c|c|c|c|c|c|c|c|}
\hline \multirow{2}{*}{$\begin{array}{c}\begin{array}{c}\text { Dependent } \\
\text { variable }\end{array} \\
\text { VARIABLES } \\
\end{array}$} & \multirow{2}{*}{$\begin{array}{c}\begin{array}{c}\text { Labour } \\
\text { productivity }\end{array} \\
\text { full sample } \\
\end{array}$} & \multirow{2}{*}{$\begin{array}{c}\text { Export } \\
\text { growth } \\
\text { full sample }\end{array}$} & \multicolumn{3}{|c|}{ Having a bank loan } & \multicolumn{2}{|c|}{$\begin{array}{c}\text { Taking out a new bank } \\
\text { loan }\end{array}$} \\
\hline & & & full sample & full sample & full sample & full sample & full sample \\
\hline age $=2$ year & $\begin{array}{c}-0.461 * * * \\
{[0.0303]}\end{array}$ & $\begin{array}{l}1.035 * * * \\
{[0.0527]}\end{array}$ & $\begin{array}{c}-0.158 * * * \\
{[0.0007]}\end{array}$ & $\begin{array}{c}-0.118^{* * *} \\
{[0.0006]}\end{array}$ & & & $\begin{array}{c}-0.0279 * * * \\
{[0.0005]} \\
\end{array}$ \\
\hline age $=3$ year & $\begin{array}{c}-0.274 * * * \\
{[0.0294]}\end{array}$ & $\begin{array}{l}0.256 * * * \\
{[0.0666]}\end{array}$ & $\begin{array}{c}-0.104 * * * \\
{[0.0007]}\end{array}$ & $\begin{array}{c}-0.0688 * * * \\
{[0.0007]}\end{array}$ & & & $\begin{array}{c}-0.0169 * * * \\
{[0.0005]}\end{array}$ \\
\hline age $=4$ year & $\begin{array}{c}-0.185^{* * *} \\
{[0.0287]} \\
\end{array}$ & $\begin{array}{l}0.196 * * * \\
{[0.0693]}\end{array}$ & $\begin{array}{c}-0.0637^{* * *} \\
{[0.0008]}\end{array}$ & $\begin{array}{c}-0.0304 * * * \\
{[0.0008]}\end{array}$ & & & $\begin{array}{c}-0.00999 * * * \\
{[0.0006]} \\
\end{array}$ \\
\hline age $=5$ year & $\begin{array}{c}-0.116^{* * *} \\
{[0.0306]}\end{array}$ & $\begin{array}{l}0.160 * * * \\
{[0.0496]}\end{array}$ & $\begin{array}{c}-0.0368 * * * \\
{[0.0009]}\end{array}$ & $\begin{array}{c}-0.00586 * * * \\
{[0.0009]}\end{array}$ & & & $\begin{array}{c}-0.00611 * * * \\
{[0.0006]} \\
\end{array}$ \\
\hline age $=6$ year & $\begin{array}{c}-0.0867 * * * \\
{[0.0321]}\end{array}$ & $\begin{array}{l}0.211 * * * \\
{[0.0628]}\end{array}$ & $\begin{array}{c}-0.0210 * * * \\
{[0.0009]}\end{array}$ & $\begin{array}{c}0.00770 * * * \\
{[0.0009]}\end{array}$ & & & $\begin{array}{c}-0.00483 * * * \\
{[0.0006]} \\
\end{array}$ \\
\hline age $=7$ year & $\begin{array}{l}-0.0489 \\
{[0.0311]}\end{array}$ & $\begin{array}{l}0.0825^{*} \\
{[0.0483]}\end{array}$ & $\begin{array}{c}-0.0147 * * * \\
{[0.00098]}\end{array}$ & $\begin{array}{c}0.0118^{* * *} \\
{[0.0009]}\end{array}$ & & & $\begin{array}{c}-0.00478 * * * \\
{[0.0007]} \\
\end{array}$ \\
\hline age $=8$ year & $\begin{array}{l}-0.125^{*} \\
{[0.0759]} \\
\end{array}$ & $\begin{array}{c}0.0299 \\
{[0.0323]}\end{array}$ & $\begin{array}{c}-0.0117^{* * *} \\
{[0.0010]}\end{array}$ & $\begin{array}{l}0.0132 * * * \\
{[0.00098]}\end{array}$ & & & $\begin{array}{c}-0.00571^{* * *} \\
{[0.0007]} \\
\end{array}$ \\
\hline age $=9$ year & $\begin{array}{l}-0.0292 \\
{[0.0318]} \\
\end{array}$ & $\begin{array}{c}0.0116 \\
{[0.0351]}\end{array}$ & $\begin{array}{c}-0.0104 * * * \\
{[0.0010]}\end{array}$ & $\begin{array}{c}0.0124 * * * \\
{[0.0010]}\end{array}$ & & & $\begin{array}{c}-0.00513^{* * *} \\
{[0.0007]} \\
\end{array}$ \\
\hline age $=10$ year & $\begin{array}{c}-0.016 \\
{[0.0289]}\end{array}$ & $\begin{array}{l}0.0838 * * \\
{[0.0365]}\end{array}$ & $\begin{array}{c}-0.0102 * * * \\
{[0.00101]} \\
\end{array}$ & $\begin{array}{c}0.0110 * * * \\
{[0.0010]}\end{array}$ & & & $\begin{array}{c}-0.00509 * * * \\
{[0.0007]} \\
\end{array}$ \\
\hline age $=11$ year & $\begin{array}{l}0.00224 \\
{[0.0282]}\end{array}$ & $\begin{array}{l}-0.0101 \\
{[0.0451]}\end{array}$ & $\begin{array}{c}-0.0115^{* * *} \\
{[0.0011]}\end{array}$ & $\begin{array}{c}0.00794 * * * \\
{[0.0010]} \\
\end{array}$ & & & $\begin{array}{c}-0.00370 * * * \\
{[0.0007]} \\
\end{array}$ \\
\hline age $=12$ year & $\begin{array}{c}0.0189 \\
{[0.0273]}\end{array}$ & $\begin{array}{l}0.0880 * \\
{[0.0502]}\end{array}$ & $\begin{array}{c}-0.0159 * * * \\
{[0.0011]}\end{array}$ & $\begin{array}{c}0.00227^{* *} \\
{[0.0010]} \\
\end{array}$ & & & $\begin{array}{c}-0.00417^{* * *} \\
{[0.0007]} \\
\end{array}$ \\
\hline age $=13$ year & $\begin{array}{l}0.00891 \\
{[0.0305]}\end{array}$ & $\begin{array}{l}-0.0189 \\
{[0.0330]}\end{array}$ & $\begin{array}{c}-0.0162^{* * *} \\
{[0.0011]}\end{array}$ & $\begin{array}{l}-0.00011 \\
{[0.0010]}\end{array}$ & & & $\begin{array}{c}-0.00360 * * * \\
{[0.0007]} \\
\end{array}$ \\
\hline age $=14$ year & $\begin{array}{l}-0.0306 \\
{[0.0612]}\end{array}$ & $\begin{array}{l}-0.0218 \\
{[0.0295]}\end{array}$ & $\begin{array}{c}-0.0162^{* * *} \\
{[0.0011]} \\
\end{array}$ & $\begin{array}{c}-0.00285^{* * *} \\
{[0.0011]} \\
\end{array}$ & & & $\begin{array}{c}-0.00342^{* * *} \\
{[0.0008]} \\
\end{array}$ \\
\hline size $=$ small & $\begin{array}{c}0.360 * * * \\
{[0.0397]}\end{array}$ & $\begin{array}{c}0.266 * * * \\
{[0.0148]}\end{array}$ & & $\begin{array}{c}0.362 * * * \\
{[0.0009]}\end{array}$ & $\begin{array}{c}0.371 * * * \\
{[0.0009]}\end{array}$ & $\begin{array}{c}0.254 * * * \\
{[0.0008]}\end{array}$ & $\begin{array}{c}0.252 * * * \\
{[0.0008]}\end{array}$ \\
\hline size $=$ medium & $\begin{array}{l}0.707 * * * \\
{[0.00734]} \\
\end{array}$ & $\begin{array}{c}0.333 * * * \\
{[0.0168]}\end{array}$ & & $\begin{array}{l}0.454 * * * \\
{[0.0018]}\end{array}$ & $\begin{array}{c}0.465 * * * \\
{[0.0018]}\end{array}$ & $\begin{array}{c}0.358^{* * *} \\
{[0.0019]}\end{array}$ & $\begin{array}{c}0.354 * * * \\
{[0.0019]}\end{array}$ \\
\hline size $=$ large & $\begin{array}{l}0.888^{* * *} \\
{[0.0151]}\end{array}$ & $\begin{array}{l}0.392^{* * *} \\
{[0.0213]}\end{array}$ & & $\begin{array}{l}0.469 * * * \\
{[0.0038]}\end{array}$ & $\begin{array}{c}0.482^{* * *} \\
{[0.0038]}\end{array}$ & $\begin{array}{l}0.356 * * * \\
{[0.0041]}\end{array}$ & $\begin{array}{c}0.352^{* * *} \\
{[0.0041]}\end{array}$ \\
\hline Observations & $3,152,913$ & 507,326 & $4,183,013$ & $4,183,013$ & $4,183,013$ & $4,183,013$ & $4,183,013$ \\
\hline R-squared & 0.258 & 0.075 & 0.062 & 0.131 & 0.123 & 0.108 & 0.109 \\
\hline
\end{tabular}

Note: Robust standard errors in brackets. ${ }^{* * *} p<0.01,{ }^{* *} p<0.05, * p<0.1$. 2-digit industry and year fixed effects are included. Control group for age is $15+$, for size is micro firms. 